\title{
Working
}

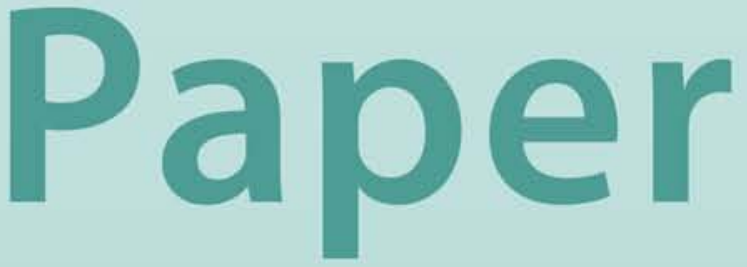




\section{Public Spending on Health Care and the Poor}

Sanjeev Gupta, Marijn Verhoeven, and Erwin Tiongson 


\title{
IMF Working Paper
}

\author{
Fiscal Affairs Department
}

Public Spending on Health Care and the Poor

Prepared by Sanjeev Gupta, Marijn Verhoeven, and Erwin Tiongson ${ }^{1}$

September 2001

\begin{abstract}
The views expressed in this Working Paper are those of the author(s) and do not necessarily represent those of the IMF or IMF policy. Working Papers describe research in progress by the author(s) and are published to elicil comments and to further debate.
\end{abstract}

This paper estimates the impact of public spending on the poor's health status in over 70 countries. It provides evidence that the poor have significantly worse health status than the rich and that they are more favorably affected by public spending on health care. An important new result is that the relationship between public spending and the health status of the poor is stronger in low-income countries than in higher-income countries. However, the results suggest that increased public spending alone will not be sufficient to meet international commitments for improvements in health status.

JEL Classification Numbers: I12, I18, I30

Keywords: public spending, health, poverty

Author’s E-Mail Address: sgupta@imf.org, mverhoeven@imf.org, etiongson@imf.org

\footnotetext{
${ }^{1}$ The authors wish to thank Emanuele Baldacci, Benedict Clements, Hamid Davoodi, Emmanuela Gakidou, Robert Gillingham, Gabriela Inchauste, Dean Jamison, Gary King, and Martin Ravallion for helpful comments and I-Lok Chang for technical assistance. The authors are especially indebted to P.A.V.B. Swamy for his generous advice and assistance in the preparation of Appendix II.
} 


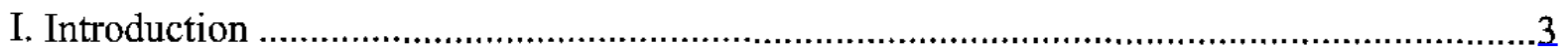

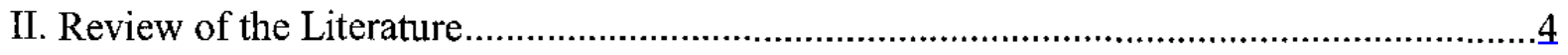

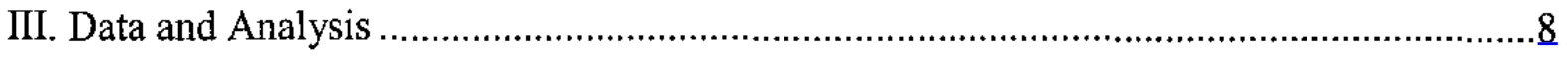

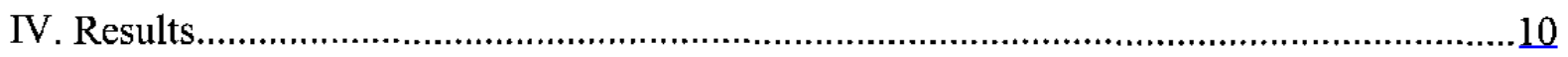

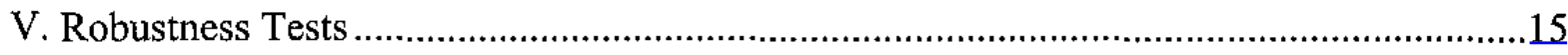

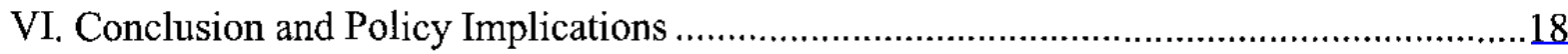

Tables

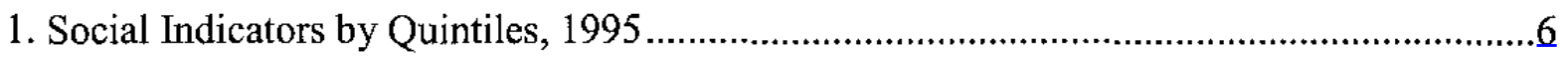

2. Public Health Spending and Child Mortality: Evidence from Quintile Data, 1990-99 ......10

3. Public Health Spending and Child Mortality: Evidence from Modified Quintile Data,

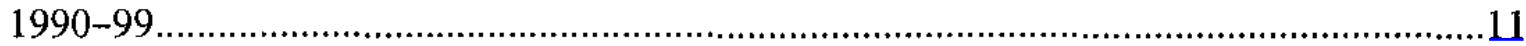

4. Health Status of the Poor and Nonpoor, 1990-99 ..................................................12

5. Public Spending and Health Status: Evidence from Ecological Inference, 1990-99 .........13

6. Coefficient Estimates from Log-linear Regressions, 1990-99 ....................................14

7. Public Spending and Health Status: Robustness Test, 1990-99 .................................15

8. Public Spending and Child Mortality: Robustness Test, 1990-99 ...............................17

Appendices

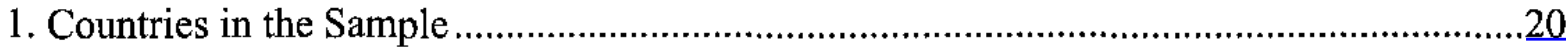

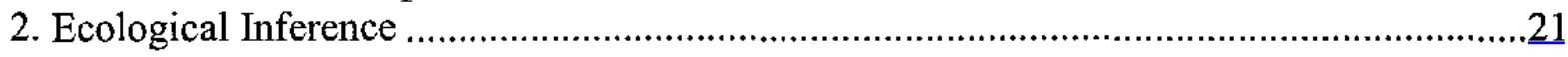

Appendix Table

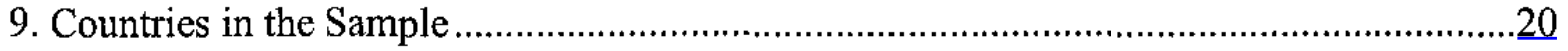

Appendix Figures

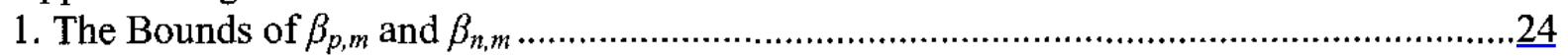

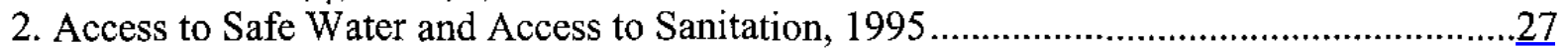

3. Child Mortality Rate of the Poor and Nonpoor, 1990-99 ............................................29

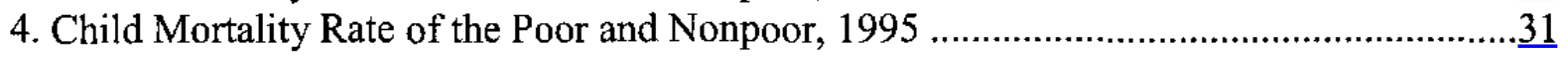

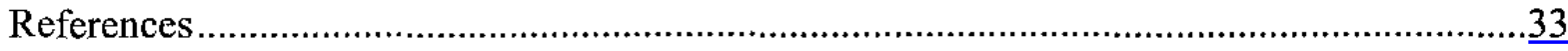




\section{INTRODUCTION}

The need to "invest in people" is the cornerstone of the new consensus on antipoverty strategies. The debate on how to find the resources for increased investment in education, health, and other areas important for the poor is intense and ongoing. Underlying this debate is the belief that such investments generate a pay-off for the poor. However, the existing literature has up to now failed to provide unambiguous evidence supporting the notion that the poor can be helped by increasing public spending for education and health care.

A number of national and international initiatives aim to increase propoor public spending, particularly in education and health care. A key international program for poverty reduction is the Heavily Indebted Poor Countries (HIPC) Initiative. ${ }^{2}$ Debt-service payments of countries receiving debt relief under the Enhanced Initiative are expected to drop, on average, by 1.9 percentage points of GDP a year during 2001-03, relative to what was paid in 1998-99 (Gupta and others, 2001). ${ }^{3}$ The resources freed up by debt relief will be significant relative to current levels of expenditure on health care and education. The 1.9 percentage points of GDP released every year is equivalent to roughly 50 percent and 90 percent of public spending in 1999 on education and health care, respectively, in HIPCs that reached the decision point as of mid-2001. The success of HIPCs and other countries in increasing propoor spending is also widely regarded as crucial for meeting the International Development Goals (IDGs). ${ }^{5}$ According to these goals, child and infant mortality rates should be reduced by two-thirds from their 1990 level by 2015 .

${ }^{2}$ The HIPC Initiative is a comprehensive approach to debt reduction that involves coordinated action by the international financial community, including multilateral creditors like the IMF and the World Bank. Launched in 1996, the HIPC Initiative aims to reduce the external debt burden of the world's poorest countries to sustainable levels and places debt relief within an overall framework of poverty reduction. Enhancements made in 1999 further strengthened the links between debt relief, poverty reduction, and social policies.

${ }^{3}$ The weighted average of the fall in debt service is 1.6 percentage points.

${ }^{4}$ At the decision point, the IMF, the World Bank, and the international community commit resources to providing sufficient assistance by the next stage, the completion point, for a country to achieve debt sustainability. The 23 countries that reached the decision point as of mid-2001 and are in our sample are listed in Appendix I.

${ }^{5}$ The IDGs represent commitments made by the UN membership at global conferences in the first half of the 1990s. These can be summarized as seven goals with 21 indicators (International Monetary Fund and others, 2000). Efforts are currently underway to reconcile the IDGs with goals adopted at the UN Millennium Summit in September 2000. 
The question is whether the increase in public outlays on education and health care as a result of new initiatives will necessarily benefit the poor and, if so, whether these spending increases will likely contribute to the achievement of the IDGs.

Empirical evidence concerning the impact of public spending on the health status of a country's population is mixed. ${ }^{6}$ Because data on the distribution of indicators by income classes are rarely available, existing studies have typically relied on aggregate health indicators. As a result, these studies do not necessarily reveal anything about the impact of spending on the poor. This issue has been raised by Bidani and Ravallion (1997), who found that the poor have worse health status than others and that public spending on health care matters more to them.

This paper assesses the health status of the poor in over 70 developing and transition economies. It does so by using actual aggregate data and a recent solution to the problem of "ecological inference," a solution initially developed for analyzing voter behavior but was subsequently applied to a broader range of political science issues (King, 1997). This technique yields more accurate disaggregated estimates than those previously used in the literature. Our results show that the poor have significantly worse health status than the nonpoor and that they are more favorably affected by public spending on health care. We also find that the relationship between public spending on health care and the health status of the poor is stronger among low-income countries than in other countries. This indicates that there may be higher returns to health spending in low-income countries, when compared to other countries.

\section{REVIEW OF THE LITERATURE}

As noted earlier, cross-country studies estimating the relationship between public health spending and health status have typically used data on aggregate indicators of health status. While there is evidence that cross-country analyses based on aggregate data are consistent with the findings of microlevel findings (Schultz, 1993 and 1998), this approach has limitations. Aggregate data on indicators often mask important variations in health status and health service use by income groups within developing and transition countries. Studies have found, for example, that

- the poor are significantly less healthy than the rich (Wagstaff, 2000; Gwatkin, 2000; Wagstaff and Watanabe, 2000);

- the rich are more likely to obtain medical care when sick (Makinen and others, 2000; Castro-Leal and others, 1999); and

\footnotetext{
${ }^{6}$ See, for example, Jack (1999); Filmer and Pritchett (1999); Gupta, Verhoeven, and Tiongson (1999).
} 
- $\quad$ the poor are more likely than the rich to obtain health care from publicly provided facilities (Gwatkin 1999 and 2000). ${ }^{7}$

These studies suggest that public spending on health may matter more to the poor, a surmise supported by Bidani and Ravallion (1997). ${ }^{8}$

In addition, several studies have suggested that public spending on health care reduces poorrich differences in health status. For example, using multivariate regression, Le Grand (1987) finds a negative, albeit weak, correlation between health inequality and the share of public spending on health care. For a sample of sub-Saharan countries, Brockerhoff and Hewett (2000) report significant correlations between child mortality differentials among ethnic groups, on the one hand, and household economic status, education of women, and access to health services, on the other hand. Gakidou and King (2000) develop a statistical method to estimate the distribution of risk of death among children under the age of two in 50 developing countries. They find that GDP per capita, health expenditures per capita, and the percent of the population earning less than one international dollar per day are all negatively correlated with health inequality; the relationship between health inequality and expenditure on health is strong at lower levels of income. Similarly, the World Bank (1995) reports that public expenditure on health in the Philippines contributes to a reduction in infant mortality rates in poorer regions, but not in richer regions.

Until recently, limited data on health were available by household income or expenditure, and rarely did existing disaggregated data allow for cross-country comparisons. Such data has recently become available. Demographic Health Surveys (DHS) were tabulated to produce summary measures of health status by wealth or asset quintiles for 44 developing and transition economies for the mid-1990s (Gwatkin and others, 2000). Table 1 reports selected summary statistics. If it is assumed that the lowest quintile or the bottom 20 percent of the population proxies the poor, the data suggest that, indeed, the health status of the poor is significantly worse than that of the nonpoor.

\footnotetext{
${ }^{7}$ Inequalities in health care are not unique to developing countries. These problems are welldocumented for advanced economies as well. See for example Benzeval, Taylor, and Judge (2000), van Doorslaer and others (1997), or Le Grand (1987).

${ }^{8}$ Deolalikar's (1995) findings are less clear. In a sample of Indonesian households, he finds that the marginal impact of public health spending on the incidence and duration of children's illness is slightly larger among the poor than the nonpoor. However, in terms of nutritional outcomes, the poor benefit less from public spending than the nonpoor. Deolalikar suggests that this may be due to a skewed distribution of health subsidies.
} 
Table 1. Sociad Indicators by Quintiles, 1995

(Number of countries in parentheșes)

\begin{tabular}{|c|c|c|c|c|c|c|c|c|c|c|c|c|}
\hline & \multirow{2}{*}{\multicolumn{4}{|c|}{ Sub-Saharan }} & \multirow{2}{*}{\multicolumn{2}{|c|}{ Asia $(7)$}} & \multirow{2}{*}{\multicolumn{2}{|c|}{$\begin{array}{c}\text { Westen } \\
\text { Hemisphere (9) }\end{array}$}} & \multirow{2}{*}{\multicolumn{2}{|c|}{$\begin{array}{c}\text { Transition } \\
\text { Fconomies (3) }\end{array}$}} & \multirow{2}{*}{\multicolumn{2}{|c|}{ Other $^{3}(3)$}} \\
\hline & & & & & & & & & & & & \\
\hline & Q1 & Q5 & Q! & Q5 & $\mathrm{Ql}$ & Q5 & Q1 & Q5 & $\mathrm{QH}$ & $Q 5$ & $\overline{\mathrm{Ql}}$ & $\overline{Q 5}$ \\
\hline Births attended by skilled staff $(\%)$ & 31 & 84 & 25 & 82 & 16 & 68 & 40 & 94 & 96 & 100 & 23 & 88 \\
\hline \multicolumn{13}{|l|}{ Moriality rate (per thousand births) } \\
\hline Infant mortality rate & 91 & 51 & 107 & 67 & 80 & 41 & 69 & 29 & 56 & 41 & 96 & 31 \\
\hline Child mortality rate & 148 & 74 & 192 & 105 & 118 & 53 & 97 & 37 & 68 & 45 & 128 & 35 \\
\hline \multicolumn{13}{|l|}{ Malnutrition } \\
\hline Children Stunted $(\%)$ & 41 & 18 & 41 & 23 & 57 & 30 & 36 & 6 & 35 & 16 & 38 & 11 \\
\hline Children Underweight (\%moderate) & 32 & 14 & 36 & 18 & 57 & 29 & 19 & 4 & 16 & 8 & 19 & 5 \\
\hline \multicolumn{13}{|l|}{ Immunization rate $(\%)$} \\
\hline Immunization rate, DPT & 49 & 76 & 43 & 79 & 47 & 81 & 52 & 75 & 70 & 38 & 61 & 95 \\
\hline Immunization rate, measies & 55 & 78 & 47 & 80 & 50 & 82 & 65 & 82 & 80 & 34 & 69 & 93 \\
\hline
\end{tabular}

Source: Gwatkin and others (2000)

${ }^{1} \mathrm{Q} 1$ is the poorest 20 percent of the population, $Q 5$ is the richest. The survey years range from 1990-98. On average, they are for 1995 .

${ }^{2}$ Unweighted average.

${ }^{3}$ Egypt, Morocco, and Turkey.

The quintile statistics reported in Table 1 are based on an asset index derived from principal components analysis. Data on income are unavailable in DHS so the asset index is used to proxy living standards. The index has been shown by some studies to be comparable with traditional measures of living standards. ${ }^{9}$ But this measure of poverty is relative. The "poor" in one country are not necessarily comparable with the "poor" in another country. 10

A distribution of health status based on an internationally comparable cut-off point, such as an international poverty line, would be a better measure of the outcomes for the poor across countries. "In the absence of actual data on variations in health status by income, Bidani and Ravallion (1997) use the two-dollar-a-day poverty line to decompose aggregate health indicators into subgroup averages for 35 countries. ${ }^{12}$ They estimate the health status of the

${ }^{9}$ See Filmer and Pritchett (2001) and Montgomery and others (1999) for a detailed discussion of proxy measures of living standards.

${ }^{10}$ See Filmer (2000, p. 9) for a related discussion.

${ }^{11}$ When the poor are identified using the two-dollar-a-day poverty line, the poverty headcount ranges from 1.6 (Poland) to 96 (Ghana) percent of the population.

${ }^{12}$ A similar method was used by Prescott and Jamison (1985) to decompose aggregate indicators of public health resource availability into averages for urban and rural areas. 
poor and nonpoor, defined as the population living below and above the two-dollar-a-day poverty line, respectively, using a random coefficients model. ${ }^{13}$

Bidani and Ravallion's approach has some methodological weaknesses (see also Appendix II). They use a specific model of health status to estimate the distribution of aggregate health indicators. ${ }^{14}$ The accuracy of the estimates is therefore sensitive to the particular model of health status adopted. Bidani and Ravallion's approach also does not take into account available information on the reasonable range of values for the relevant health indicators. As originally implemented, their approach report the average health indicators for the poor and nonpoor, using the means of the explanatory variables, without retrieving the country-level estimates. In general, when restrictions are not properly specified in regressions of this form, the estimated country-level subgroup means may lie beyond their reasonable range. A reproduction of their results shows that in as many as 35 percent of the underlying country-level estimates, the nonpoor could have higher child mortality rates than the poor (see Appendix II), an unlikely scenario. But more importantly, 7-16 percent of the countries in the sample are estimated to have a negative figure for child mortality - a physical impossibility.

King (1997) develops a methodology for estimating disaggregated data that addresses these weaknesses (see also Appendix II). It assumes random coefficients, allowing the distribution of health status to vary from country to country. ${ }^{15}$ In addition, it restricts the disaggregated data (which are specified as proportions) to the appropriate intervals, in particular, the [0,1] interval or narrower. It also does not assume an explicit health production function and thus avoids problems associated with misspecification. Simulations (reproduced in Appendix II) show that King's method provides a good approximation of actual disaggregated data.

${ }^{13}$ See Swamy and Tavlas (2001) for a survey of the literature on random coefficient models.

${ }^{14}$ In Bidani and Ravallion's model, health is a function of initial primary school enrollment ratio at the country level, public spending on health per capita at the country level, and mean consumption per person of each subgroup. The parameter estimates from their cross-country regression allow them to decompose the aggregate indicator into subgroup averages.

${ }^{15}$ The methodology is a solution to the ecological inference problem. In general, the problem of ecological inference concerns the use of aggregate data to infer discrete individual-level relationships. Bidani and Ravallion's (1997) approach is similar to what is known in the ecological inference literature as "Goodman's regression." Unlike the classic Goodman's regression, however, Bidani and Ravallion's method includes control variables and assumes random coefficients. King's solution also uses a random coefficients model, and, in addition, places restrictions on the estimated parameters, and assumes a convenient distribution for local parameters. This methodology is described in detail in King (1997), King, Rosen, and Tanner (1999), and Benoit and King (1996). 
This paper follows King's methodology to construct disaggregated data for the health status of the poor and nonpoor in various countries, using aggregate country-level data on health indicators and the poverty headcount. We employ the statistical procedure used by King as programmed in EzI version 2.3 (see Benoit and King, 1996 and King, 1997). ${ }^{16}$ Using these estimates of the health status of the poor and nonpoor, we then regress health status on its known determinants, including public spending on health care at the country level.

\section{DATA AND ANALYSIS}

The empirical analysis is done in two steps. First, health indicators (child and infant mortality rates and births attended by skilled staff) for the poor and nonpoor are estimated using aggregate health indicators and poverty headcount based on the two-dollar-a-day poverty measure. Data on aggregate health indicators are drawn from the World Development Indicators (WDI) database while data on poverty headcount for 82 developing and transition economies are drawn from a recent update of statistics reported in Ravallion and Chen (1997).

Second, the following regression equation is estimated:

$$
Y_{i j}=\alpha_{j}+\beta^{\prime}{ }_{j} X_{i}+\gamma^{\prime}{ }_{j} Z_{i j}+\varepsilon_{i j}
$$

where $Y_{i j}$ is the mean indicator for the $j$ th subgroup in country $i ; X_{i}$ is a vector of explanatory variables for country $i$; and $Z_{i j}$ is a vector of explanatory variables for group $j$ in country $i$. The baseline model uses the same explanatory variables as Bidani and Ravallion, that is, initial primary school enrollment ratio at the country level, ${ }^{17}$ public spending on health per capita at the country level, and mean consumption per person of subgroup $j .{ }^{18}$ Other known determinants of health, such as private spending on health care, are added to test the robustness of the results.

\footnotetext{
${ }^{16}$ By using this procedure, Gakidou, Jamison, King, and Spohr (1999) have generated estimates of the probability of dying and tuberculosis prevalence among the poor and nonpoor for the World Health Report 1999.
}

${ }^{17}$ Initial enrollment ratio refers to enrollment in 1980 . The results reported below also hold when the initial enrollment ratio refers to 1985 .

${ }^{18}$ In general public spending and the other covariates are assumed to have an impact on health status, that is measured (with error) by standard health indicators, such as child mortality rates. If health status is a latent variable, ignoring the measurement error could lead to biased estimates of the parameters. We do not attempt to address this issue in this paper. See Baldacci and de Mello (forthcoming). 
We use two specifications to estimate the relationship between health status and its determinants: (1) log-linear (log-log or double log) specification, where all the variables are logarithmic, and (2) linear-log (lin-log) specification, where the dependent variable is linear and the regressors are logarithmic. These functional forms have the added convenience of providing parameter estimates that are the implied elasticities and the absolute change in health status associated with a percent change in spending, respectively. The issue of correct functional form is an outstanding issue in the literature. ${ }^{19} \mathrm{We}$ do not attempt to settle it in this paper. Instead we use functional forms that have been previously used in the literature to investigate the statistical relationship between health status and public spending on health care. $^{20}$

Data on public spending on health care per capita are drawn from national authorities and IMF staff estimates. These have the advantage of being taken from a consistent set of fiscal data. ${ }^{21}$ Per capita health spending is measured in PPP terms. ${ }^{22}$ Data on the enrollment ratio and urbanization are drawn from the WDI database. Data on mean consumption per person are calculated from Ravallion and Chen (1997). ${ }^{23}$ Unless otherwise indicated, the variables are the country averages for the $1990-99$ period. $^{24}$

${ }^{19}$ See, for example, Kakwani (1993).

${ }^{20}$ Various functional forms have been used in the literature including log-linear, semi-log, and logistic (dichotomous) regressions. Bidani and Ravallion (1997) use a linear specification. All the regression results described in this paper also hold for linear regressions. The results with respect to the health status of the poor have higher statistical significance in the linear regressions than egressions reported in this paper.

${ }^{21}$ An alternative data source for health spending per capita in U.S. dollars is the World Health Report 2000. Although not necessarily consistent with overall budget data, data on both private and public spending are available from this source, mostly for 1997 . We use them in the section on robustness tests. Data from the two sources are strongly correlated, with a correlation coefficient of 0.8 .

${ }^{22}$ Per capita PPP public spending on health is calculated as the product of health spending as a share of GDP in local currency and GDP per capita expressed in PPP terms. This follows Gupta and Verhoeven (2001).

${ }^{23}$ We calculate the mean consumption or expenditure per person in each subgroup using the poverty headcount, the poverty gap, the poverty line, and the mean consumption per person for the country as a whole.

${ }^{24}$ Data have been averaged over the 1990-99 period because of the unavailability of annual data particularly for health indicators for a number of countries. Therefore, this paper does not attempt to distinguish between lagged and current impact of public health spending on health indicators. See also Gupta and Verhoeven (2001). 


\section{RESUlts}

To start with, we run an OLS regression of equation (1) using quintile data on the child mortality rate from DHS. The regression results of the baseline model are reported in columns (1), (2), (5) and (6) in Table 2, where child mortality is a function of public spending on health per capita, initial primary school enrollment, and mean consumption per capita for the relevant subgroup. In the absence of data on consumption or expenditure in DHS, mean consumption per capita by subgroup is proxied by multiplying data on quintile expenditure share by the average per capita GDP. ${ }^{25}$ Columns (3), (4), (7) and (8) add private health spending per capita to the baseline model. ${ }^{26}$ The results suggest that public spending on health is a consistent, significant determinant of the child mortality rate among the poor. In contrast, there is some evidence that the nonpoor rely more on private resources.

Table 2. Public Health Spending and Child Mortality: Evidence from Quintile Dala, 1990-99 (Heteroskedastic-consistent t-statistics in parentheses)

\begin{tabular}{|c|c|c|c|c|c|c|c|c|}
\hline & \multicolumn{4}{|c|}{ Poor (Q1) } & \multicolumn{4}{|c|}{ Vonpoor (Q5) } \\
\hline & $\begin{array}{c}\text { (1) } \\
\text { Log-linear }\end{array}$ & $\begin{array}{c}\text { (2) } \\
\text { Lititlog }\end{array}$ & $\begin{array}{c}\text { (3) } \\
\text { Log-linear }\end{array}$ & $\begin{array}{c}\text { (4) } \\
\text { Lin-log }\end{array}$ & $\begin{array}{c}(5) \\
\text { Loy-linear }\end{array}$ & $\begin{array}{c}(6) \\
\text { Lis-log }\end{array}$ & $\begin{array}{c}7) \\
\text { Logg-linear }\end{array}$ & $\begin{array}{c}(8) \\
\text { Lin-log }\end{array}$ \\
\hline Constante & $\begin{array}{l}9.23 * * * \\
(17.24)\end{array}$ & $\begin{array}{l}745.85^{* * *} \\
(9.37)\end{array}$ & $\begin{array}{l}9.17^{* * *} \\
(17.10)\end{array}$ & $\begin{array}{l}735.75^{* * * *} \\
(9.29)\end{array}$ & $\begin{array}{l}10.65^{\circ * * 4} \\
(19.87)\end{array}$ & $\begin{array}{l}546.29^{* * *} \\
(10.41)\end{array}$ & $\begin{array}{l}10.29 * * * * \\
(21.46)\end{array}$ & $\begin{array}{l}520.24^{* * *} \\
(10.58)\end{array}$ \\
\hline Pablic health spending per capita & $\begin{array}{l}-0.32^{* * *} \\
(-4.10)\end{array}$ & $\begin{array}{l}-37.01^{* 8 \times x} \\
(-3.71)\end{array}$ & $\begin{array}{l}-0.30^{* * *} \\
(-364)\end{array}$ & $\begin{array}{l}-33.54^{* * *} \\
(-3.23)\end{array}$ & $\begin{array}{l}-0.02 \\
(-0.22)\end{array}$ & $\begin{array}{l}-5.27 \\
(-0.81)\end{array}$ & $\begin{array}{l}-0.02 \\
(-0.24)\end{array}$ & $\begin{array}{l}-5.39 \\
(-0.78)\end{array}$ \\
\hline Iritial primary enrollment ratio & $\begin{array}{l}-0.23^{* * *} \\
\{-2.69)\end{array}$ & $\begin{array}{l}-37.69^{* 8} \\
(-2.35)\end{array}$ & $\begin{array}{l}-0.23^{* * *} \\
(-2.78)\end{array}$ & $\begin{array}{l}-37.82^{* *} \\
(-2.41)\end{array}$ & $\begin{array}{l}-0.37 * * * \\
(-4.26)\end{array}$ & $\begin{array}{l}-38.95^{* * * *} \\
(-3.86)\end{array}$ & $\begin{array}{l}-0.38^{* * *} \\
(-5.34)\end{array}$ & $\begin{array}{l}-40.24^{* * * *} \\
(-4.35)\end{array}$ \\
\hline Quintile income per capita & $\begin{array}{l}-0.13^{*} \\
(-185)\end{array}$ & $\begin{array}{l}-31.16^{* *} \\
(-2.85)\end{array}$ & $\begin{array}{l}-0.12 \\
(-0.99)\end{array}$ & $\begin{array}{l}-24.48^{*} \\
(-1.85)\end{array}$ & $\begin{array}{l}-0.69 * * * \\
(-5.59)\end{array}$ & $\begin{array}{l}-38.17^{* * *} \\
(-4.21)\end{array}$ & $\begin{array}{l}-0.52^{* * * *} \\
(-3.75)\end{array}$ & $\begin{array}{l}-25.91^{* \star} \\
(-2.31)\end{array}$ \\
\hline Private health spending per capita & & & $\begin{array}{l}-0.07 \\
(-0.63)\end{array}$ & $\begin{array}{l}-13.13 \\
(-1.08)\end{array}$ & & & $\begin{array}{l}-0.19 * * * \\
(-2.53)\end{array}$ & $\begin{array}{l}-14.44 \\
(-2.23)\end{array}$ \\
\hline Adjusted R-squared & 0.65 & 0.69 & 0.64 & 0.69 & 0.81 & 0.75 & 0.83 & 0.78 \\
\hline Number of observations & 32 & 32 & 32 & 32 & 32 & 32 & 32 & 32 \\
\hline F-statistic & $20.27 * * *$ & $24.35^{k * *}$ & $15.13^{* * *}$ & $18.72^{* 2 *}$ & $45.18^{* * *}$ & $33.68^{* * * 4}$ & $39.57^{* * *}$ & $28.68^{* * *}$ \\
\hline
\end{tabular}

Source: See text.

$(* *),\left(^{* *}\right)$, and $(*)$ denote significance at the 1,5 , and 10 percent levels, respectively.

However, as noted earlier, the quintile measures of the poor and nonpoor are not necessarily comparable across countries. An alternative measure of the health status of the absolute poor and nonpoor can be obtained by using DHS quintile data and the poverty headcount based on the two-dollar-a-day poverty line (see Appendix II for details). For example, the averages of

${ }^{25}$ Data on quintile income shares are from the WDI. This measure of quintile expenditure or income follows several antecedents in the literature, including Deininger and Squire (1998) and Dollar and Kraay (2001). It should be kept in mind, however, that these are income quintiles while DHS quintile data are based on asset or wealth quintiles. Therefore, the regression results should be interpreted with caution.

${ }^{26}$ Data on private spending are from the World Health Report 2000. 
child mortality rate of the lowest two quintiles found to be poor on the basis of the twodollar-a-day poverty line would proxy the health status of the poor.

The baseline model is run again using the new dependent variable estimated above as a function of public spending on health per capita, initial primary school enrollment for the country as a whole, and mean consumption per capita for the relevant subgroup. The results are reported in Table 3 . While public spending on health per capita is a significant determinant of the health status of the nonpoor, it has a larger impact on the health status of the poor, both in terms of the implied elasticities and in absolute terms. Similarly, the initial primary enrollment ratio has a higher marginal impact on the poor. As in Table 3, the nonpoor are able to rely more on private resources. Mean consumption per capita is insignificant and in some cases has the "wrong" sign, but this is driven in part by collinearity. ${ }^{27}$ The results should be interpreted with caution: this is a rough approximation of the health status of the absolute poor based on quintile averages, for a relatively small sample of countries. In addition, the poverty headcount and the DHS asset quintile data are based on two different measures of the standard of living.

Table 3. Public Health Spending and Child Mortality: Evidence from Modified Quintile Data. 1990-99 (Heteroskedastic-consistent t-statistics in parentheses)

\begin{tabular}{|c|c|c|c|c|c|c|c|c|}
\hline & \multicolumn{4}{|c|}{ Poor ${ }^{1}$} & \multicolumn{4}{|c|}{ Nimporr ${ }^{1}$} \\
\hline & $\begin{array}{c}\text { (lj) } \\
\text { Log-linear }\end{array}$ & $\begin{array}{c}(3) \\
\text { Lin-log }\end{array}$ & $\begin{array}{c}\text { (3) } \\
\text { T.org-linear }\end{array}$ & $\begin{array}{c}\text { (4) } \\
\text { I.in-log }\end{array}$ & $\begin{array}{c}\text { (5) } \\
\text { f.og-linear }\end{array}$ & $\begin{array}{c}(6) \\
\text { I in-ligy }\end{array}$ & $\begin{array}{c}(7) \\
\text { Iog-linear }\end{array}$ & $\begin{array}{c}\text { (3) } \\
\text { Iin-log }\end{array}$ \\
\hline Constant & $\begin{array}{l}9.52^{* 4 * *} \\
(1.307)\end{array}$ & $\begin{array}{l}794.71^{* * *} \\
(7.96)\end{array}$ & $\begin{array}{l}9.17 * 6 * \\
(10.56)\end{array}$ & $\begin{array}{l}744.17^{* * *} \\
(707)\end{array}$ & $\begin{array}{l}\left.10.3\right|^{* \text { *w* }} \\
(10.38)\end{array}$ & $\begin{array}{l}634.24^{\text {*Hx }} \\
(6.38)\end{array}$ & $\begin{array}{l}8.49 * * * \\
(8.67)\end{array}$ & $\begin{array}{l}431.15^{* * *} \\
(4.21)\end{array}$ \\
\hline Public health spending per capita & $\begin{array}{l}-0.32^{* * * *} \\
(-3.6[)\end{array}$ & $\begin{array}{l}-3402^{* * * *} \\
(-3.21)\end{array}$ & $\begin{array}{l}-0.26 * * \\
(-2.46)\end{array}$ & $\begin{array}{l}-25.17 * * \\
(-2.30)\end{array}$ & $\begin{array}{l}-0.30^{* \star} \\
(-3.26)\end{array}$ & $\begin{array}{l}-31.60^{* * *} \\
(-3.37)\end{array}$ & $\begin{array}{l}-0.23 * * \\
(-2.77)\end{array}$ & $\begin{array}{l}-23.48^{* * * *} \\
(-3.20)\end{array}$ \\
\hline initial primary enrollment ratıo & $\begin{array}{l}-0.39 * * * * \\
(-3.60)\end{array}$ & $\begin{array}{l}-62.23^{* * * *} \\
(-3.52)\end{array}$ & $\begin{array}{l}-0.38 * * * \\
(3.87)\end{array}$ & $\begin{array}{l}-61.34 * * * \\
(-3.71)\end{array}$ & $\begin{array}{l}-0.43^{* * *} \\
(-3.18)\end{array}$ & $\begin{array}{l}-0.52^{* *} \\
(-2.77)\end{array}$ & $\begin{array}{l}-0.41 * * * \\
(4.21)\end{array}$ & $\begin{array}{l}-50.53^{* * * *} \\
(-3.50)\end{array}$ \\
\hline Mean consumption per person & $\begin{array}{l}-0.13 \\
(-0.55)\end{array}$ & $\begin{array}{l}-3431 \\
(-1.21)\end{array}$ & $\begin{array}{l}-0.05 \\
(-0.19)\end{array}$ & $\begin{array}{l}-23.72 \\
(-0.76)\end{array}$ & $\begin{array}{l}-0.30 \\
(-1.25)\end{array}$ & $\begin{array}{l}-11.25 \\
(-0.55)\end{array}$ & $\begin{array}{l}0.12 \\
(0.45)\end{array}$ & $\begin{array}{l}36.30 \\
(1.29)\end{array}$ \\
\hline Private health spending per capita & & & $\begin{array}{l}-0.12 \\
(-1.11)\end{array}$ & $\begin{array}{l}-17.73 \\
(-1.56)\end{array}$ & & & $\begin{array}{l}-0.28 * * * \\
(-3.37)\end{array}$ & $\begin{array}{l}-31.41^{* * *} \\
(-2.84)\end{array}$ \\
\hline Adjusted R-squared & 0.58 & 0.65 & 0.59 & 0.67 & 0.64 & 0.61 & 0.71 & 0.70 \\
\hline Number of observations & 29 & 29 & 29 & 29 & 29 & 29 & 29 & 29 \\
\hline F-statistic & $14.41^{* * * *}$ & $1905^{* * *}$ & 1] $40^{* * * *}$ & $15.61^{* * * *}$ & $17.72^{* * *}$ & $15.73 * * *$ & $18.58^{* \pi *}$ & $17.36 \times \times k$ \\
\hline
\end{tabular}

Source: See text.

$\left({ }^{* * *}\right),(* *)$. and $(*)$ denote significance at the 1,5 . and 10 percent levels. respectively

'These are estimated using DI IS data and the poverty headcount as described in the text.

The baseline model is rerun once again using estimates of health indicators generated from ecological inference. These estimates provide twice as many country observations. ${ }^{28}$

${ }^{27}$ Mean consumption per capita is highly correlated with public health spending per capita and private health spending per capita. In a bivariate regression of health status on mean consumption per capita, the implied elasticity is about 0.8 .

${ }^{28}$ Although King's methodology seems to perform relatively well in estimating the health status of the poor, it is less precise in capturing the health status of the nonpoor. This result 
Estimates of the health status of the poor and nonpoor using ecological inference are presented in Table 4. ${ }^{29}$ As expected, across all country groups, the poor have significantly worse health status than the nonpoor. In the case of child mortality rate, the average for the poor is about six times that of the nonpoor. In sub-Saharan Africa, the mortality rate of the poor is more than seven times that of the nonpoor. ${ }^{30}$

\begin{tabular}{|c|c|c|c|c|c|c|c|}
\hline & \multicolumn{3}{|c|}{ Sub-Saharan } & \multirow{2}{*}{$\begin{array}{c}\text { Western } \\
\text { Hemisphere }\end{array}$} & \multirow[b]{2}{*}{ Other' } & \multirow{2}{*}{$\begin{array}{l}\text { Transition } \\
\text { Economies }\end{array}$} & \multirow{2}{*}{$\begin{array}{c}\text { Sample } \\
\text { Size }\end{array}$} \\
\hline & All & Africa & Asia & & & & \\
\hline Child mortality rate (per 1,000 live births) & 81.0 & 162.9 & 71.4 & 42.1 & 60.3 & 35.1 & 76 \\
\hline Poor & 136.8 & 206.8 & 101.0 & 92.1 & 170.3 & 105.9 & 76 \\
\hline Nonpoor & 23.4 & 28.7 & 31.3 & 18.9 & 31.0 & 13.9 & 76 \\
\hline Infant mortality rate (per 1,000 live births) & 54.9 & 98.4 & 53.2 & 33.7 & 50.0 & 26.7 & 76 \\
\hline Poor & 88.6 & 120.9 & 71.1 & 67.4 & 109.0 & 73.5 & 76 \\
\hline Nonpoor & 23.2 & 32.0 & 26.4 & 16.8 & 33.4 & 13.0 & 76 \\
\hline Births attended by health staff ( $\%$ of total) & 61.5 & 44.3 & 52.7 & 77.2 & 61.0 & 90.6 & 58 \\
\hline Poor & 50.2 & 34.8 & 45.1 & 64.6 & 37.1 & 86.4 & 58 \\
\hline Nunpoor & 80.2 & 75.9 & 74.0 & 88.3 & 68.1 & 95.9 & 58 \\
\hline
\end{tabular}

Sources: World Development Indicalors database; and authors' calculations.

${ }^{1}$ Middle Eastern and North African countries.

Table 5 reports the log-linear and lin-log regression results for child mortality rates and births attended by skilled staff. The results for infant mortality rates (not shown) are similar to those of child mortality rates. For births attended by skilled staff in columns (3), (4), (7) and (8), the patterns follow those reported in Table 2 and Table 3: public health spending is a stronger determinant of health status among the poor. Similarly, initial primary school enrollment matters more for the poor's health status, with a comparable elasticity (about 0.50). Mean consumption per person in each subgroup is not significant and, in some cases, has the "wrong" sign but this seems to be driven largely by collinearity with health spending and enrollment ratio. ${ }^{31}$

holds for a small sample of countries for which DHS data are available. See Appendix II, pp. $31-32$.

${ }^{29}$ A list of 76 countries included in the sample is provided in Appendix II.

${ }^{30}$ It should be kept in mind, however, that the nonpoor are defined to also include those that are very close to the poverty line, i.e., the nonpoor are not just the rich.

${ }^{31}$ In a bivariate regression, for example, births attended by skilled staff has an elasticity with respect to mean consumption per capita of about 0.7 among the poor and about 0.3 among the nonpoor. This is significant at the 1 percent level. 
Table 5. Public Spending and Health Stanus: Evidence from Ecological Inlerence, 1990-99

(White's t-statistics in parentheses)

\begin{tabular}{|c|c|c|c|c|c|c|c|c|}
\hline & \multicolumn{4}{|c|}{ Poor } & \multicolumn{4}{|c|}{ Nonpoor } \\
\hline & \multicolumn{2}{|c|}{ Child mortality rate } & \multicolumn{2}{|c|}{ Births attended by skilled staft } & \multicolumn{2}{|c|}{ Child mortality rate } & \multicolumn{2}{|c|}{ Births attended by skilled stall } \\
\hline & $\begin{array}{c}\text { Log-linear } \\
\text { (1) }\end{array}$ & $\begin{array}{l}\text { Lin-log } \\
\text { (2) }\end{array}$ & $\begin{array}{c}\text { Log-iinear } \\
\text { (3) }\end{array}$ & $\begin{array}{l}\text { Lin-log } \\
\text { (4) }\end{array}$ & $\begin{array}{c}\text { Loy-linear } \\
\text { (5) }\end{array}$ & $\begin{array}{c}\text { Lin-log } \\
(6)\end{array}$ & $\begin{array}{c}\text { Log-linear } \\
\text { (7) }\end{array}$ & $\begin{array}{c}\text { I, in-log } \\
(8)\end{array}$ \\
\hline Constant & $\begin{array}{l}7.95^{* * *} \\
(10.27)\end{array}$ & $\begin{array}{l}635.93^{* * *} \\
(4.92)\end{array}$ & $\begin{array}{l}-1.79 \\
(-1.49)\end{array}$ & $\begin{array}{l}-173.64^{* * * *} \\
(-4.91)\end{array}$ & $\begin{array}{l}4.01^{* * *} \\
(3.41)\end{array}$ & $\begin{array}{l}5.79 \\
(0.12)\end{array}$ & $\begin{array}{l}3.53^{* * * *} \\
(4.54)\end{array}$ & $\begin{array}{l}20.09 \\
(0.49)\end{array}$ \\
\hline Public health spending per capita & $\begin{array}{l}-0.19 * * * \\
(-2.68)\end{array}$ & $\begin{array}{l}-26.65^{* * *} \\
(-295)\end{array}$ & $\begin{array}{l}0.50^{* * *} \\
(4.33)\end{array}$ & $\begin{array}{l}18.49^{* 4 * *} \\
(6.61)\end{array}$ & $\begin{array}{l}-0.32^{* * * *} \\
(-4.37)\end{array}$ & $\begin{array}{l}-9.17 * * \\
(-2.33)\end{array}$ & $\begin{array}{l}0.22^{* * *} \\
(2.93)\end{array}$ & $\begin{array}{l}13.04^{* * * *} \\
(3.54)\end{array}$ \\
\hline Irvitial primary enrollment ratio & $\begin{array}{l}-0.48^{* * * *} \\
(-3.66)\end{array}$ & $\begin{array}{l}-64.60 \\
(-3.84)\end{array}$ & $\begin{array}{l}0.51^{* *} \\
(2.13)\end{array}$ & $\begin{array}{l}13.73 * * \\
(2.37)\end{array}$ & $\begin{array}{l}0.01 \\
(0.09)\end{array}$ & $\begin{array}{l}5.22 \\
(0.68)\end{array}$ & $\begin{array}{l}0.05 \\
(0.47)\end{array}$ & $\begin{array}{l}2.28 \\
(042)\end{array}$ \\
\hline Mean consumption per person & $\begin{array}{l}0.16 \\
(0.60)\end{array}$ & $\begin{array}{l}4.14 \\
(0.10)\end{array}$ & $\begin{array}{l}-0.26 \\
(-0.78)\end{array}$ & $\begin{array}{l}3.39 \\
(0.31)\end{array}$ & $\begin{array}{l}0.33 \\
(1.24)\end{array}$ & $\begin{array}{l}14.25 \\
(1.43)\end{array}$ & $\begin{array}{l}-0.25 \\
(-1.38)\end{array}$ & $\begin{array}{l}-11.12 \\
(-1.07)\end{array}$ \\
\hline Adjusted R-squared & 0.24 & 0.35 & 0.50 & 0.49 & 0.39 & 0.24 & 0.29 & 0.38 \\
\hline Number of observations & 67 & 67 & 52 & 52 & 67 & 67 & $\$ 2$ & 52 \\
\hline F-statistic & $8.19 * * *$ & $13.09^{* * *}$ & $1814^{* * *}$ & $17.68 * * *$ & $15.38^{* * *}$ & $8.00 * * 2$ & $7.97 * * *$ & $11.42^{* * * *}$ \\
\hline
\end{tabular}

Source: See text

$(* * *),\left({ }^{* *}\right)$, and $(*)$ denote significance at the 1,5 , and 10 percent levels, respectively

For the child mortality rate in the log-linear regression results reported in columns (1) and (5), public spending on health care is a significant determinant of health status of both the poor and nonpoor. A higher elasticity of the child mortality rate with respect to public health spending is observed among the nonpoor. However, as reported in Table 4, the poor and nonpoor have widely divergent average child mortality rates per 1,000 live births. This implies that in absolute terms (in terms of number of deaths per 1,000 live births), spending has a larger impact on the poor. This is confirmed by the results of the lin-log regressions in columns (2) and (6), where the parameter estimates are the implied absolute change in the child mortality rate associated with a percent increase in the independent variables. A one percent increase in public spending on health reduces child mortality by twice as many deaths among the poor. ${ }^{32}$ Infant mortality rates follow this same pattern. ${ }^{33}$

The results in Table 5 present separate regressions for the poor and nonpoor. When the two samples are pooled to run the Chow breakpoint test, the result suggests that the coefficients of the two sets of regressions are significantly different. This provides evidence that pooling is not appropriate and that, as indicated by the coefficient estimates, public spending matters more to the poor.

${ }^{32}$ A strictly linear regression. following Bidani and Ravallion, shows that a unit increase in public spending on health reduces child mortality by three times as many deaths among the poor compared to the nonpoor.

${ }^{33}$ The implied public expenditure elasticity of the infant mortality rate is comparable to Bidani and Ravallion's (1997) estimate. 
There is evidence that the elasticities are not constant across countries. Kakwani (1993) has previously suggested that the income elasticity of health status varies with per capita income at the country level. In his analysis, the income elasticity of infant mortality rate is observed to decrease monotonically with income. Similarly, Gakidou and King (2000) find that the impact of both income and expenditure on health status is stronger at lower levels of income.

To examine the impact of spending on the poor among low-income countries, the sample is divided into countries eligible for assistance from the World Bank and the IMF under the IDA and PRGF facility and those that are not. ${ }^{34}$ Table 6 provides the new regression results for a sample of PRGF-eligible countries and non-PRGF countries.

Table 6. Coefficient Estimates from Log-linear Regressions, 1990-99

(Elasticity of child mortality rates with respect to public spending on health)

\begin{tabular}{|c|c|c|c|c|c|c|}
\hline & \multicolumn{2}{|c|}{ Model 1} & \multicolumn{2}{|c|}{ Model 2} & \multicolumn{2}{|c|}{ Model 3} \\
\hline & PRGF & Non-PRGF & PRGF & Non-PRGF & PRGF & Non-PRGF \\
\hline Poor & $\begin{array}{l}-0.32 * * * \\
(-3.30)\end{array}$ & $\begin{array}{l}-0.06 \\
(-0.58)\end{array}$ & $\begin{array}{l}-0.36^{* * * *} \\
(-2.94)\end{array}$ & $\begin{array}{l}-0.03 \\
(-0.33)\end{array}$ & $\begin{array}{l}-0.28 * * * \\
(-2.78)\end{array}$ & $\begin{array}{l}-0.07 \\
(-0.69)\end{array}$ \\
\hline Nonpoor & $\begin{array}{l}-0.29 * * * \\
(-2.63)\end{array}$ & $\begin{array}{l}-0.29 * * * \\
(-2.39)\end{array}$ & $\begin{array}{l}-0.32^{* * *} \\
(-2.69)\end{array}$ & $\begin{array}{l}-0.28 * * * \\
(-2.63)\end{array}$ & $\begin{array}{l}-0.27^{* *} \\
(-2.49)\end{array}$ & $\begin{array}{l}-0.33 * * * \\
(-3.01)\end{array}$ \\
\hline Sample size & 29 & 38 & 29 & 38 & 29 & 38 \\
\hline
\end{tabular}

Source: See text.

$\left({ }^{* *}\right),\left({ }^{* *}\right)$, and $\left({ }^{*}\right)$ denote significance at the 1,5 , and 10 percent levels, respectively.

'Model 1 is the baseline model; model 2 is the base line model plus controls for private spending and urbanization; and model 3 is the baseline model plus private spending, urbanization and a dummy for Sub-Saharan Africa.

The implied elasticities in Table 6 indicate that in countries with lower levels of income, public health spending has a higher impact on the health status of the poor. Given the prevailing higher levels of child mortality in low-income countries, the effect of public

${ }^{34}$ The Poverty Reduction and Growth Facility (PRGF) is the IMF's lending facility for lowincome countries. It calls for an explicit focus on poverty reduction in the context of a growth-oriented strategy. The targets and policies embodied in PRGF-supported programs are derived from the country's own poverty reduction strategy. PRGF eligibility is based primarily on a country's per capita income and eligibility for assistance under the International Development Association (IDA). The current cut-off point for IDA eligibility is the 1999 per capita GDP of $\$ 885$. 
spending is more pronounced when measured in absolute terms. This result is robust to the inclusion of other control variables. However, the results show the absence of a statistically significant association between public spending on health care and the health status of the poor among the non-PRGF countries in the sample. This could be due to inefficiencies in the provision of services and poor targeting in these countries that weaken the impact of public spending on health.

\section{Robustness TESTS}

Public spending on health. Table 7 replicates the regressions in Table 5, using public health spending data drawn from the WHO (2000). Although the implied elasticities are higher, the patterns in the two tables are similar. For both the poor and the nonpoor, public spending on health care is a significant determinant of health status. For the child mortality rate, the estimated public expenditure elasticity for the nonpoor is higher than the poor; in absolute terms, however, public spending has a bigger impact on the poor. The coefficient estimates suggest that the same percent increase in spending translates into twice the number of deaths prevented among the poor, compared to the nonpoor. For births attended by skilled staff, public spending on health consistently has a bigger impact on the poor, for both log-linear estimates and lin-log estimates.

Table 7. Public Spending and Heaith Status: Robustness Test, 1990-99 (White's t-statislics it parentheses)

\begin{tabular}{|c|c|c|c|c|c|c|c|c|}
\hline & \multicolumn{4}{|c|}{ Poor } & \multicolumn{4}{|c|}{ Nonpour } \\
\hline & \multicolumn{2}{|c|}{ Child mortality rate } & \multicolumn{2}{|c|}{ Births attended by skilled staft } & \multicolumn{2}{|c|}{ Cbild mortality rate } & \multicolumn{2}{|c|}{ Births attended by skilled staff } \\
\hline & $\begin{array}{l}\text { Log-linear } \\
\text { (1) }\end{array}$ & $\begin{array}{l}\text { Lin-log } \\
\text { (2) }\end{array}$ & $\begin{array}{c}\text { Log-linear } \\
\text { (3) }\end{array}$ & $\begin{array}{l}\text { Lin-log } \\
\text { (4) }\end{array}$ & $\begin{array}{l}\text { Log-linear } \\
(5)\end{array}$ & $\begin{array}{c}\text { Lin-log } \\
(6)\end{array}$ & $\begin{array}{c}\text { Log-linear } \\
\text { (7) }\end{array}$ & $\begin{array}{c}\text { I.in-log } \\
(8)\end{array}$ \\
\hline Constant & $\begin{array}{l}6.48^{* * *} \\
(8.45)\end{array}$ & $\begin{array}{l}428.35 * * * \\
(3.93)\end{array}$ & $\begin{array}{l}0.63 \\
(0.47)\end{array}$ & $\begin{array}{l}-86.48 * * \\
(-2.07)\end{array}$ & $\begin{array}{l}1.29 \\
(1.12)\end{array}$ & $\begin{array}{l}-86.25 \\
(-1.18)\end{array}$ & $\begin{array}{l}4.99^{* * * *} \\
(6.17)\end{array}$ & $\begin{array}{l}101.09^{* * *} \\
(2.18)\end{array}$ \\
\hline Public bealth spending per capita & $\begin{array}{l}-0.30^{* * *} \\
(-4.61)\end{array}$ & $\begin{array}{l}39.68^{* * * *} \\
(-4.80)\end{array}$ & $\begin{array}{l}0.45 * * * \\
(3.71)\end{array}$ & $\begin{array}{l}17.15^{* * * *} \\
(5.14)\end{array}$ & $\begin{array}{l}-0.43^{* * 2} \\
(-5.56)\end{array}$ & $\begin{array}{l}-13.73^{* *} \\
(-2.47)\end{array}$ & $\begin{array}{l}0.22^{* * *} \\
(3.01)\end{array}$ & $\begin{array}{l}13.18^{* * * *} \\
(3.82)\end{array}$ \\
\hline Initial primary enrollment ratio & $\begin{array}{l}-0.30 * * * \\
(-2.55)\end{array}$ & $\begin{array}{l}-40.71^{* *} \\
(-2.36)\end{array}$ & $\begin{array}{l}0.42 \\
(1.56)\end{array}$ & $\begin{array}{l}10.67 \\
(1.47)\end{array}$ & $\begin{array}{l}0.14 \\
(1.10)\end{array}$ & $\begin{array}{l}10.18 \\
(1.18)\end{array}$ & $\begin{array}{l}0.003 \\
(0.02)\end{array}$ & $\begin{array}{l}-0.78 \\
(-0.14)\end{array}$ \\
\hline Mean consumption per person & $\begin{array}{l}0.24 \\
(0.98)\end{array}$ & $\begin{array}{l}14.60 \\
(0.45)\end{array}$ & $\begin{array}{l}-0.17 \\
(-0.50)\end{array}$ & $\begin{array}{l}6.28 \\
(0.52)\end{array}$ & $\begin{array}{l}0.56^{* *} \\
(2.43)\end{array}$ & $\begin{array}{l}23.76^{*} \\
(1.95)\end{array}$ & $\begin{array}{l}-0.30 \\
(-1.60)\end{array}$ & $\begin{array}{l}-13.42 \\
(-1.34)\end{array}$ \\
\hline Adjusted R-squared & 0.33 & 0.42 & 0.42 & 0.43 & 0.49 & 0.40 & 0.26 & 0.34 \\
\hline Vumber of observations & 71 & 71 & 56 & 56 & 71 & 71 & 56 & 56 \\
\hline F-statistic & $12.77 * *$ & $18.56^{\text {**** }}$ & $14.72 * * *$ & $15.40^{* * *}$ & $23.45^{* *}$ & $16.92^{* * 4 *}$ & $7.65^{* * *}$ & $10.78^{* * *}$ \\
\hline
\end{tabular}

Source: See text.

$\left(^{* * *}\right),\left({ }^{* *}\right)$, and $\left({ }^{*}\right)$ denote signilicance at the 1,5 , and 10 percent levels, respectively.

The primary school enrollment ratio is a significant determinant of child mortality and infant mortality (not shown) among the poor; the magnitude of its impact is comparable to public 
spending on health. On the other hand, mean consumption per person in each subgroup still has the "wrong sign." As in Table 4 and Table 5, this may be due to multicollinearity. ${ }^{35}$

Other determinants of health. Table 8 reproduces the regressions in Table 7 using data on public health spending from the World Health Report 2000, controlling for other known determinants of health status. First, individuals may protect themselves against health risks by relying on out-of-pocket expenditure on health care. A suitable test would be the addition of a control variable for private spending on health care. Second, studies report that mortality is higher for rural, low-income, agricultural households, suggesting that increased urbanization is associated with improved health status of the population (see for example Schultz, 1993). Urban areas may also provide better access to health facilities (Prescott and Jamison, 1985). ${ }^{36}$

Third, HIV infection is generally thought to have a significant impact on child mortality rates in developing countries (Stanton, 1994). Models 1 to 3 in Table 7 add these variables to the baseline model: private spending on health, urbanization, and adult HIV prevalence.

The pattern indicated in Table 8 is similar to those in Tables 5 and 7. The absolute impact of public health spending on the health status of the poor is more than twice that of the nonpoor, across all models. Private spending on health care is also a significant determinant of the health status of the poor (not shown). The magnitude, however, is small: it is less than half the impact of public health spending. This confirms, to some extent, previous findings in the literature that the poor rely more on publicly provided services. Meanwhile, urbanization is statistically insignificant. In contrast, adult HIV prevalence has a significant impact on health status, as expected. A percentage point increase in adult HIV prevalence, for example, is associated with about three more deaths per 1000 live births.

The regression results with respect to infant mortality rates and births attended by skilled staff are likewise robust to the inclusion of additional control variables. In contrast to the observed insignificant impact of urbanization child mortality rate, however, urbanization is significantly associated with more births attended by skilled staff. This may indicate

\footnotetext{
${ }^{35}$ A bivariate regression of health status on mean consumption per person indicates that consumption or expenditure elasticity ranges from -0.2 to -0.7 . In general, consumption or expenditure elasticity is higher among the poor in these bivariate regressions.

${ }^{36}$ While there is substantial evidence that urban areas enjoy lower child mortality rates, Stanton (1994) cautions that the relationship between urbanization and child health is quite complex. For example, in some countries, mortality rates in urban slum areas are significantly higher than in rural areas. In urban areas, there can be more high technology health care facilities but fewer primary health care facilities. In addition, across countries, it is difficult to disentangle the effects of urbanization, industrialization, and economic prosperity.
} 
Table 8. Public Spending and Child Mortality: Robustness Tests, 1990-99 ${ }^{\mathrm{l}}$

(Elasticity of child mortality rate with respect to public spending on health)

\begin{tabular}{|c|c|c|c|c|c|c|}
\hline & \multicolumn{2}{|c|}{ Model 1} & \multicolumn{2}{|c|}{ Model 2} & \multicolumn{2}{|c|}{ Model 3} \\
\hline & Log-linear & Lin- $\log$ & Log-linear & Lin-log & Log-linear & Lin-log \\
\hline Poor & $\begin{array}{l}-0.24 * * * \\
(-3.19)\end{array}$ & $\begin{array}{l}-34.35^{* * *} \\
(-3.05)\end{array}$ & $\begin{array}{l}-0.19^{* *} \\
(-2.45)\end{array}$ & $\begin{array}{l}-35.95^{* *} \\
(-2.38)\end{array}$ & $\begin{array}{l}-0.28^{* * *} \\
(-2.94)\end{array}$ & $\begin{array}{l}-38.81^{*} \\
(-2.45)\end{array}$ \\
\hline Nonpoor & $\begin{array}{l}-0.43^{* * *} \\
(-5.06)\end{array}$ & $\begin{array}{l}-14.44^{* *} \\
(-2.38)\end{array}$ & $\begin{array}{l}-0.44^{* * *} \\
(-4.76)\end{array}$ & $\begin{array}{l}-13.69^{* * *} \\
(-2.62)\end{array}$ & $\begin{array}{l}-0.44^{* * *} \\
(-4.50)\end{array}$ & $\begin{array}{l}-13.96^{* *} \\
(-2.56)\end{array}$ \\
\hline Sample size & 71 & 71 & 71 & 71 & 68 & 68 \\
\hline
\end{tabular}

Source: See text.

$\left({ }^{* * *}\right),\left({ }^{* *}\right)$, and $\left({ }^{*}\right)$ denote significance at the 1,5 , and 10 percent levels, respectively.

'Model 1 reproduces the regression in Table 6, controlling for private spending on health; model 2 adds

urbanization to the control variables in model 1 ; and model 3 adds adds HIV prevalence to the control

variables in model 2 .

increased access to health care facilities in urban areas. The regression results are robust to the inclusion of dummy variables for regions (Sub-Saharan Africa, Asia, Latin America and the Caribbean and others).

Benefit incidence. It can be argued that the impact of public spending on the poor reflects the incidence of such spending or the share of spending received by the poor. Deolalikar (1995) suggests that an unequal distribution of government health subsidies may lead to a lower marginal benefit of government health spending for the poor. Conversely, a higher marginal impact of spending on the health status of the poor may reflect a progressive distribution of health subsidies.

Over the last 25 years, a large volume of literature has emerged on the benefit incidence of government expenditure. A recent review of 29 developing and transition countries over the period 1978-95 finds that on average, government spending on health care is progressive but poorly targeted in sub-Saharan Africa and in transition economies. ${ }^{37}$

Testing the robustness of the results to the inclusion of a measure of benefit incidence is hampered by two major difficulties. First, benefit incidence is typically measured for quintiles, without the use of absolute poverty lines. Second, data on benefit incidence, as

${ }^{37}$ Government spending is well targeted if the poorest 20 percent receive more than the richest 20 percent, in absolute terms. It is progressive if the poorest 20 percent receive more than the richest 20 percent, relative to their income or expenditure. See Chu, Davoodi, and Gupta (2000). 
compiled by Davoodi and Sachjapinan (forthcoming) are available for only a small sample of developing and transition economies.

Notwithstanding these difficulties, we use the share of health expenditures received by the poorest quintile to proxy benefit incidence for a much smaller sample of 20 countries for which data are available. The results (not shown) are robust to the inclusion of this variable. Benefit incidence itself has the "right" sign, that is, a higher incidence is associated with lower mortality rates, but is not significant. Public spending, however, is consistently significant. This provides some preliminary evidence that the marginal benefit of public spending on health is higher among the poor, regardless of the observed share of total public spending on health received by different income groups. ${ }^{38}$

\section{CONCLUSION AND POLICY IMPLiCATIONS}

This paper finds evidence in over 70 developing and transition economies that the poor have significantly worse health status than the nonpoor and that the poor are more strongly affected by public spending on health care in comparison with the nonpoor. The same result was obtained by Bidani and Ravallion, but on the basis of a different statistical methodology.

The regression results suggest that the difference in the impact of spending between the poor and nonpoor could be substantial. For child mortality rates, a one percent increase in public spending on health reduces child mortality by twice as many deaths among the poor. Infant mortality rates follow a similar pattern. In addition, there is some evidence that the returns to public spending on health are higher among the poor regardless of the benefit incidence.

An important new result is that the relationship between public spending on health care and the health status of the poor is stronger among low-income countries. In this context, the estimates of the elasticity of health status of the poor to health spending suggest that increases in health spending that HIPCs receiving debt relief have committed to (an increase by 0.4 percentage point of GDP between 1999 and 2000/01) may lead to a reduction in child mortality rates by 5 deaths out of 1,000 live births among the poor between 1999 and $2000 / 01 .^{39}$ A similar reduction may be expected for infant mortality rates.

38 This result is similar but stronger than what is suggested by Filmer, Hammer, and Pritchett (2000); that is, given a uniform distribution of public spending on health across income groups, the impact on health status of public spending should still be larger for the poor.

${ }^{39}$ An increase in outlays on health by 0.4 percentage point of GDP is a 20 percent increase in the 1999 level of public spending on health among HIPCs that have reached the decision point (Gupta and others, 2001). We use the parameter estimates in Table 5 to calculate the implied reduction in mortality. 
While these reductions are not trivial, they are by themselves not enough for countries to reach the IDGs by 2015 . The 1990 average child and infant mortality rates for the HIPCs that have now reached the decision point are 157 and 104 deaths out of a 1,000 live births, respectively. ${ }^{40}$ This implies that an annual percent reduction in mortality rates of about 4 percent has to be achieved to reach the target of a two-thirds reduction by 2015 . If this reduction in mortality rates were to be met through increased public spending on health alone, such spending would need to rise in HIPCs from an average of 2 percent of GDP in 1999 to 12 percent of GDP in 2015 . The results presented in this paper further suggest that increasing public health spending to this level is not needed to reach the IDGs if progress is made in other areas, such as increasing female education or stimulating income growth (Demery and Walton, 1998).

Therefore, additional complementary policies are needed to achieve the IDGs. For example, resources need to be reallocated toward health interventions designed to respond primarily to the health needs of the poor. Governments also need to make sure that health interventions reach their intended beneficiaries. Our empirical results suggest a number of areas where progress is needed. First, primary school enrollment is a significant determinant of health status, particularly among the poor. ${ }^{41}$ Second, economic growth that translates into increased private resources for health care may also have a large pay-off. Finally, there is evidence that adult HIV prevalence has a large impact on child mortality rates, for both the poor and the nonpoor.

${ }^{40}$ Data are from the 2001 WDI.

${ }^{41}$ Ongoing work on rural-urban health differences, based on the premise that the poor are concentrated in rural areas, suggests that female secondary education and vaccinations have a significant, negative impact on child mortality rates in urban areas but not in rural areas. Similarly, female education has a significant impact on rural infant mortality rates (Wang, 2001). 
Appendix Table 9. Countries in the Sample

\begin{tabular}{|c|c|c|c|c|c|c|c|}
\hline Country & $\begin{array}{l}\text { PRGF- } \\
\text { Eligible }\end{array}$ & $\mathrm{HIPCs}$ & $\begin{array}{c}\text { Reached } \\
\text { Decision Point } / \\
\text { Completion Point }\end{array}$ & Country & $\begin{array}{l}\text { PRGF- } \\
\text { Eligible }\end{array}$ & HIPCs & $\begin{array}{c}\text { Reached } \\
\text { Decision Point } \\
\text { Completion Point }\end{array}$ \\
\hline Algeria & & & & Mexico & & & \\
\hline Bangladesh & $*$ & & & Moldova & $*$ & & \\
\hline Bolivia & $*$ & $*$ & * & Mongolia & * & & \\
\hline Botswana & & & & Morocco & & & \\
\hline Brazil & & & & Mozambique & $*$ & $*$ & $*$ \\
\hline Bulgaria & & & & Namibia & & & \\
\hline Burkina Faso & $*$ & $*$ & $*$ & Nepal & $*$ & & \\
\hline Cambodia & $*$ & & & Nicaragua & $*$ & $*$ & $*$ \\
\hline Central African Republic & $*$ & & & Niger & * & $*$ & $*$ \\
\hline Chile & & & & Pakistan & $*$ & & \\
\hline Colombia & & & & Panama & & & \\
\hline Costa Rica & & & & l'araguay & & & \\
\hline Cotê d'Tvoire & $*$ & $*$ & & Рenu & & & \\
\hline Dominican Republic & & & & Philippines & & & \\
\hline Ecuador & & & & Poland & & & \\
\hline Egypt & $*$ & & & Romania & & & \\
\hline El Salvador & & & & Russian Federation & & & \\
\hline Estonia & & & & Rwanda & $*$ & $*$ & * \\
\hline Ethiopia & $*$ & $*$ & & St. Lucia & $*$ & & \\
\hline Gambia, The & $*$ & $*$ & $*$ & Senegal & $*$ & & $*$ \\
\hline Ghana & $*$ & $*$ & & Sierta Leene & $*$ & $*$ & \\
\hline Guatemaia & & & & Slovak Republic & & & \\
\hline Guyana & $*$ & $*$ & & South Africa & & & \\
\hline Honduras & $*$ & $*$ & $*$ & Sri Lanka & $*$ & & \\
\hline Hungary & & & & Tanzania & $*$ & $*$ & $*$ \\
\hline Indonesia & & & & Thailand & & & \\
\hline Jamaica & & & & Trinidad and Tobago & & & \\
\hline Jordarı & & & & Tunisia & & & \\
\hline Kazakhstan & & & & Turkey & & & \\
\hline Kenya & $*$ & $*$ & & Turkmenistan & & & \\
\hline Kyrgyz Republic & * & & & Uganda & $*$ & $*$ & $*$ \\
\hline Latvia & & & & Ukraine & & & \\
\hline Eesotho & $*$ & & & Unuguay & & & \\
\hline Lithuania & & & & Uzbekistan & & & \\
\hline Madagascar & $*$ & $*$ & $*$ & Venezuela, RB & & & \\
\hline Malaysia & & & & Yernen, Rep. Of & $*$ & $*$ & \\
\hline Mali & * & $*$ & $*$ & Zambia & $*$ & $*$ & \\
\hline Mauritania & $*$ & $*$ & $*$ & Zimbabwe & $*$ & & \\
\hline
\end{tabular}

Source: IMF staff. 


\section{ECOLOGICAL INFERENCE}

The literature on ecological inference has evolved within the realm of political science, particularly in the context of the analysis of voting behavior. Independent from this literature, economists have tended to rely on various solutions to the problem of ecological inference. Bidani and Ravallion (1997) is a case in point. These solutions have been along the line of what in the ecological inference literature is known as "Goodman's regression." This appendix provides a brief overview of the problem of ecological inference and its solutions in the literature-Goodman's regression and King's (1997) methodology. It also provides empirical evidence in favor of King's method over Goodman's regression.

\section{Theoretical Issues}

The problem of inferring characteristics at the individual level from aggregate data is called "the ecological inference problem." In this paper, we use "ecological inference" to identify the health status of the poor, for which no useful observations exist. In general, the problem of ecological inference can be represented by the following accounting identity:

$$
Y_{i}=\beta_{n, i}\left(n_{i}\right)+\beta_{p, i}\left(1-n_{i}\right)
$$

where $Y_{i}$ is the aggregate indicator (e.g., voter turnout), $n_{i}$ is the population share $(0 \leq n \leq 1)$ of the subgroup of interest (e.g., the nonpoor), and $\beta_{n, i}$ and $\beta_{p, i}$ are the unknown subgroup characteristics (in the example, voter turnout of the nonpoor and the poor, respectively), here specified as proportions. Because this accounting relationship has two unknowns for every observation $i$, it is impossible to solve. This is known in the literature as "the indeterminacy problem."

One solution to (1) is to assume that the subgroup characteristics are constant across all observations:

$$
Y_{i}=\beta_{n}\left(n_{i}\right)+\beta_{p}\left(1-n_{i}\right)
$$

where $\beta_{n}$ and $\beta_{p}$ are estimated as parameters in an OLS regression of $Y_{i}$ on $\left(n_{i}\right)$ and $\left(1-n_{i}\right)$ through the origin. This has been one of the standard solutions in political science since the 1950 s. Without any explicit reference to the ecological inference literature, versions of this regression have been the basis for empirical studies in economics, including an evaluation of targeting performance in Argentina's Trabajar program (Ravallion, 1999a and 2000) ${ }^{42}$, a study of decentralized targeting in Bangladesh's food-for-education program (Galasso and Ravallion, 2001), and a rural-urban decomposition of social indicators in Indonesia (Ravallion, 1996).

${ }^{42}$ See also Ravallion (1999b) for a related theoretical model. 
In the ecological inference literature, this methodology for solving the ecological inference problem corresponds to what is known as Goodman's regression. Because the regression is typically estimated as a fixed coefficients model, the parameter estimates reflect the average subgroup characteristic (such as voter turnout in our example) and may be unrepresentative of any particular $i$. In addition, the estimated $\beta_{n}$ and $\beta_{p}$ may be outside reasonable bounds. For example, if parameters of interests are defined in population shares (as was the case in the voting models for which this approach to the ecological inference problem was initially designed), the $\beta$ 's must lie within the $[0,1]$ range. Other problems associated with Goodman's regression are discussed in detail in King (1997, pp. 56-73).

The health status of the poor and nonpoor has been estimated by Bidani and Ravallion (1997) using a method similar in form to Goodman's regression. They use the following accounting identity to estimate subgroup health indicators:

$$
Y_{i}=\sum_{j=1}^{M} Y_{i j} n_{i j}
$$

where $Y_{i}$ is the health indicators for country $i ; Y_{i j}$ is the mean indicator for the $j$ th subgroup in country $i ; n_{i j}$ is the population share of $\operatorname{subgroup} j$ in $i$, and

$$
\sum_{j=1}^{M} n_{l j}=1
$$

where $j=1, \ldots ; \mathrm{M}$ denotes the number of subgroups; and $i=1, \ldots, \mathrm{N}$ denotes the countries. A vector of explanatory variables for country $i, X_{i}$, and a vector of explanatory variables for group $j$ in country $i, Z_{i j}$ is observed:

$$
Y_{i j}=\alpha_{j}+\beta^{\prime}{ }_{j} X_{i}+\gamma^{\prime}{ }_{j i j}+\varepsilon_{i j}
$$

Substituting (4) into (2) gives

$$
Y_{i}=\sum_{j=1}^{M}\left(\alpha_{i}+\beta^{\prime}{ }_{j} X_{i}+\gamma^{\prime}{ }_{j} Z_{i j}\right) n_{i j}+u
$$

where

$$
u_{i}=\sum_{j=1}^{M} \varepsilon_{i j} n_{i j}
$$

In the absence of data on health outcomes by income or expenditure, Bidani and Ravallion estimate (6) using aggregate health indicators and cross-country data on the distribution of 
consumption, public spending on health care at the country level, initial primary school enrollment ratio at the country level and mean consumption per capita of subgroup $j$. This allows them to estimate health outcomes by subgroups, the $Y_{i j}$ 's, as well as test their determinants.

While Bidani and Ravallion's (1997) approach is similar to Goodman's regression, it differs from the classic Goodman's regression in that

- it assumes random coefficients, where the $Y_{i j}$ 's in equation (3), corresponding to the $\beta$ 's in equation (1), are assumed to vary across $i$ 's; and

- it assumes an explicit production function for the $Y_{i j}$ 's, with a vector of control variables, as shown in equation (4).

Bidani and Ravallion estimate equation (5) using the algorithm described in Swamy and Tinsley (1980) as programmed by Chang and Swamy (2001) in the Stochastic Coefficient Estimation Program (SCEP). ${ }^{43}$ Bidani and Ravallion then report the average health indicators for the poor and nonpoor, using both the unweighted and population-weighted means of the explanatory variables for their sample of 35 countries. As originally implemented, Bidani and Ravallion's method did not retrieve the country-level estimates. However, the problem of out-of-bounds estimates for the $\beta$ 's remains, where the subgroup averages are specified as proportions. In particular, it can be shown that a number of the underlying country-level estimates fall outside the reasonable range. ${ }^{44}$

King (1997) proposes a solution to the ecological inference problem that avoids the drawbacks of Goodman's regression and produces more reliable results. King does not assume a particular production function for the $\beta$ 's in equation (1) and thus avoids problems associated with misspecification. ${ }^{45}$ In addition, his method assumes random coefficients and

${ }^{43}$ See also Chang, Hallahan, and Swamy (1992); Swamy and Tavlas (2001); and Chang, Swamy, Hallahan, and Tavlas (2000).

44 One ad hoc solution would be to impose the [0,1] interval after the $\beta$ 's are estimated. In contrast, King's (1997) method imposes the permissible interval prior to the calculation of point estimates of the $\beta$ 's (see below).

${ }^{45}$ Ravallion (1996: p. 213) shows that, after trial and error, the inclusion of the appropriate control variables in a regression similar to Bidani and Ravallion's model improves the estimates of subgroup means. In practice, however, it is difficult to identify what these control variables should be. An extension of King's solution allows for the inclusion of control variables (King, 1997: pp. 169-84); however, he strongly cautions against the inclusion of such variables. He discusses a number of problems associated with adding control variables. 
estimates the local parameters $\beta_{n, i}$ and $\beta_{p, i}$ rather than the global parameters $\beta_{n}$ and $\beta_{p}$. It also takes the bounds into account and imposes inequality constraints on $\beta_{n}$ and $\beta_{p}$, thus restricting them to the $[0,1]$ interval or, if appropriate, intervals narrower than $[0,1]$. $^{46}$

In particular, equation (1) can be used to solve for one unknown in terms of the other:

$$
\beta_{p, i}=\left(\frac{Y_{i}}{1-n_{i}}\right)-\left(\frac{n_{i}}{1-n_{i}}\right) \beta_{n, i}
$$

This equation shows that $\beta_{p, i}$ is a linear function of $\beta_{n, i}$, where the intercept and the slope are known (because $Y_{i}$ and $n_{i}$ are given). Plotted in $\beta_{p, r}-\beta_{n, i}$ space with a $[0,1]$ range, the corresponding line, ${ }^{47}$ projected to the horizontal axis, shows that the true value of $\beta_{p, i}$ must fall within bounds narrower than the $[0,1]$ range.

For example, a given $i$ (say, $i=m$ ) has observed values of $\mathrm{Y}_{\mathrm{m}}=0.30$ and $\mathrm{n}_{\mathrm{m}}=0.75$. Substituting into equation (8) gives $\beta_{p, m}=1.2-3.0^{*}\left(\beta_{n, m}\right)$. This implies that for $m, \beta_{n}$ must fall within the narrow bounds of $[0.067,0.4]$ for $\beta_{p}$ to fall within $[0,1]$, as depicted in Appendix Figure 1.

\section{Appendix Figure 1. The Bounds of $\beta_{p, m}$ and $\beta_{n, m}$}

$$
\left(\mathrm{Y}_{\mathrm{m}}=0.30 \text { and } \mathrm{n}_{\mathrm{m}}=0.75\right)
$$

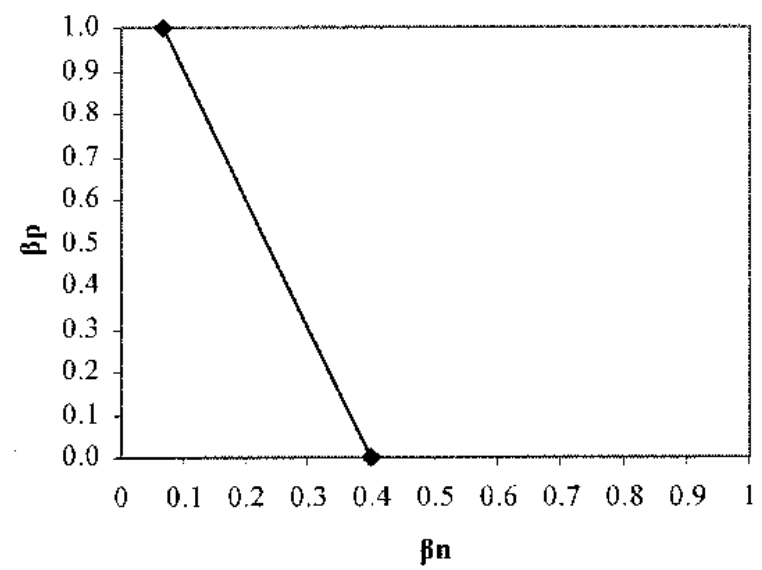

In general, lines that are relatively steep in $\beta_{p, i}-\beta_{n, i}$ space give wide bounds on $\beta_{p, i}$ and narrow bounds on $\beta_{n, i}$; on the other hand, lines that are relatively flat in this same space give narrow bounds on $\beta_{p, i}$ and wide bounds on $\beta_{n, i}$. Lines that cut the bottom left or top right corners of

${ }^{46}$ The methodology is drawn, in part, from Duncan and Davis (1953).

${ }^{47}$ King refers to this as a tomography line. 
the graph give narrow bounds to both parameters. The range of $\beta$ 's may be narrowed down as follows:

$$
\begin{aligned}
& \max \left(0, \frac{Y_{i}-n_{i}}{1-n_{i}}\right) \leq \beta_{p, i} \leq \min \left(\frac{Y_{i}}{1-n_{i}}, 1\right) \\
& \max \left(0, \frac{Y_{i}-\left(1-n_{i}\right)}{n_{i}}\right) \leq \beta_{n, i} \leq \min \left(\frac{Y_{i}}{n_{i}}, 1\right)
\end{aligned}
$$

Additional information in the other observations in the dataset ( $Y_{i}$ and $n_{i}$ for all $i$ not equal to $m$ ) is then used to learn more about the probabilistic values of $\beta_{p}$ and $\beta_{n}$ in $m$ within the permissible bounds, using Bayesian statistics. In particular, King assumes a truncated bivariate normal distribution from which $\beta_{p, i}$ and $\beta_{n, i}$ are drawn. First; a maximum likelihood function is used to estimate the parameters that define the shape of this distribution. King then uses this hypothetical distribution as a prior for simulating values of $\beta_{p}$ and $\beta_{n}$ in every $i$ within the known permissible bounds. The point estimates are the means of the simulated distribution and the standard error is the degree of variation in the simulated values.

Further details are provided in King (1997), King, Rosen, and Tanner (1999), and Benoit and King (1996).

\section{Empirical Evidence}

King (1997) presents an array of robustness and sensitivity tests. He also assesses how well the new method performs with actual data. The method performs well in four datasets for which disaggregated data on the variable of interest are available. Because of the inequality constraints, the parameter estimates are never as far from their actual values as when Goodman's regression is applied.

As with all other methods of ecological inference, however, it is not guaranteed to work perfectly. Some information is still lost in the aggregation. In addition, in practice, King's method allows for only two subgroups while Bidani and Ravallion's method allows for any number of subgroups. ${ }^{48}$ For a more detailed analysis of multiple income groups, for example, King's method may not be appropriate. For the purposes of this paper, however, we found King's method more appropriate than other statistical techniques. In this section, we present further evidence that King's method yields a good approximation of disaggregated data.

\footnotetext{
48 There is a short, and largely conjectural, chapter on ecological inference for multidimensional tables in King (1997: pp. 263-76).
} 


\section{Rural-Urban Decomposition}

As a rough assessment of how well King's methodology of ecological inference substitutes for disaggregated observations, we compare estimates with actual values of disaggregated data for the rural-urban decomposition of (1) access to sanitation and (2) access to safe water in some 35 countries. ${ }^{49}$ For actual data we rely on the WDI database.

To estimate country-level values of rural population with access to sanitation and safe water using King's methodology, we use country-level data on rural population and aggregate access to safe water and sanitation. We employ King's solution as programmed in $E z I$ version 2.3 (see Benoit and King, 1996). To estimate country-level values of rural population with access to sanitation and safe water using Bidani and Ravallion's method, we also use country-level data on aggregate access to safe water and sanitation. The urbanization rate is used to divide the sample into two subgroups: rural and urban population. For simplicity, we model both access to safe water and access to sanitation as a function of GDP per capita. ${ }^{50}$ We estimate equation (5) using the Swamy-Tinsley algorithm as programmed in SCEP.

Appendix Figure 2 shows how estimates derived from King's method compare with estimates generated from Bidani and Ravallion's method and with actual values. The shaded areas mark the area outside the reasonable range of 0 to 100 percent.

In general, estimates from King's method follow the actual values closely; in some cases, they match perfectly. They are highly correlated (with a 0.93 correlation coefficient) and the correlation is significant at the one percent level. Diagnostic tests in $E z I$ indicate that the true values are estimated accurately by the posterior distribution of $\beta_{p}$ and $\beta_{n}$. In particular, over 80 percent of the estimates fall within the 80 percent confidence intervals for $\beta_{p}$ and $\beta_{n}$.

Country-level estimates from the Bidani-Ravallion method are also closely correlated to actual values (the correlation coefficients are over 0.8 , in both cases). In addition, the unweighted average of access to sanitation among the rural population (64) is comparable with the unweighted average of actual values and estimates from King's method ( 53 and 60, respectively). However, as the shaded region in Appendix Figure 2 shows, some of the estimated country-level values lie beyond the reasonable range of 0 to 100 percent of the rural population, as there are no prior restrictions on the bounds.

\footnotetext{
${ }^{49}$ There are two antecedents in the literature: Prescott and Jamison (1985) decomposed aggregate indicators of resource availability into means for urban and rural areas. Ravallion (1996) performed a test of the accuracy of synthetic data based on the availability of actual data on rural-urban decomposition.

${ }^{50}$ The basic results are robust to the inclusion of other potential determinants of access to safe water and sanitation.
} 
Appendix Figure 2. Access to Safe Water and Access to Sanitation, 1995 (In percent of rural population)

Rural population with access to sanitation in 33 countries

- King's method - Bidani-Ravallion method o Actual valucs

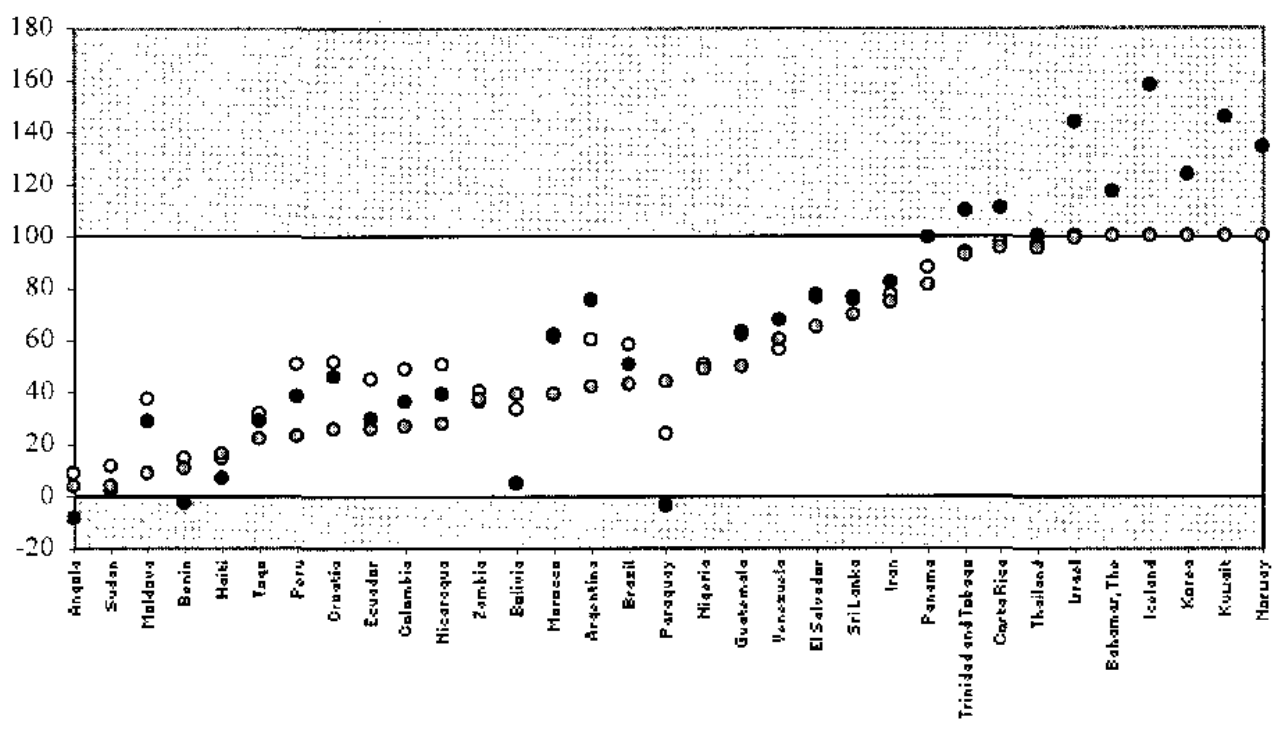

Rural population with access to safe water in 35 countries

- King's method • Bidani-Ravallion method • Actual values

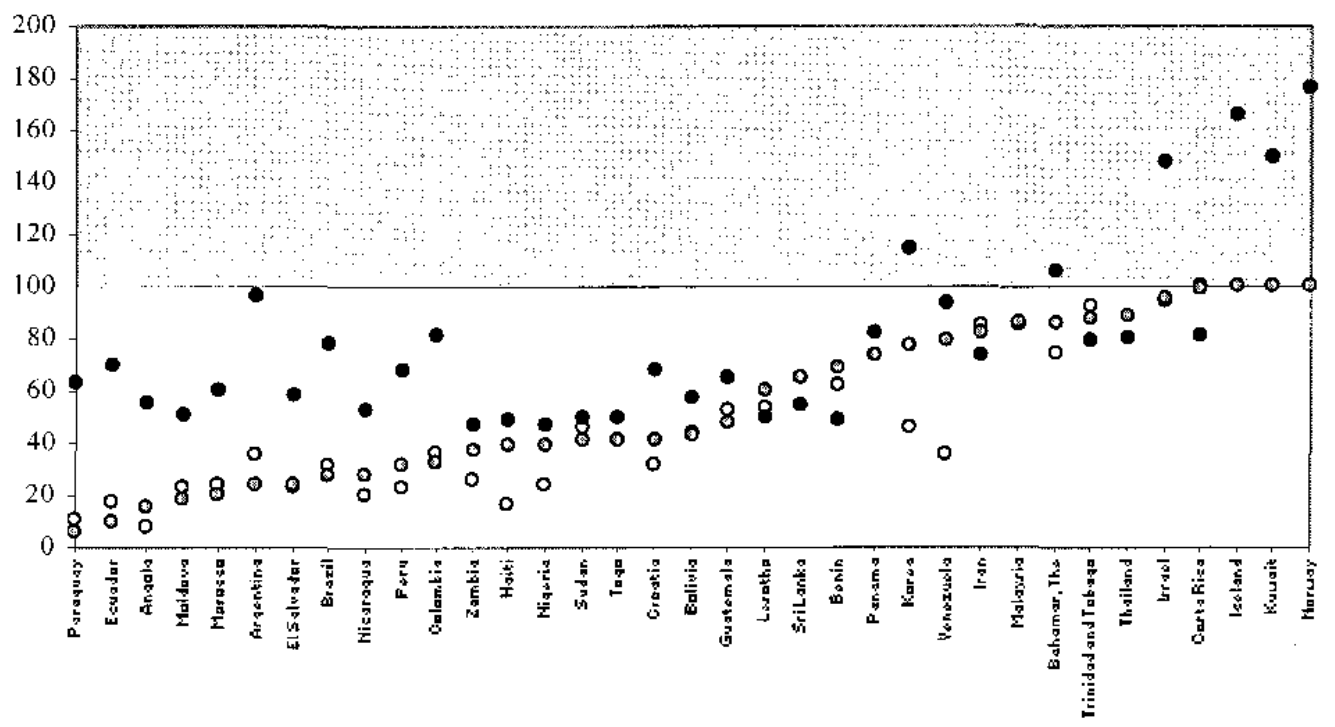

Source: World Development Indicators database; and authors' calculations. 


\section{Health Status of the Poor and Nonpoor}

As noted earlier, Bidani and Ravallion (1997) use Goodman's regression, with random coefficients, to assess the health status of the poor. Here we assess how the results they obtain compare with those found with King's method.

Following Bidani and Ravallion, we estimate equation (5) for a sample of 68 developing and transition economies using aggregate child mortality rate and cross-country data on the distribution of consumption, public spending on health care at the country level, initial primary school enrollment ratio at the country level and mean consumption per capita of subgroup $j$. The two-dollar-a-day international poverty line is used as the cut-off for dividing the sample into two subgroups: the poor and the nonpoor. We estimate the model using SCEP.

We also estimate a regression of equation (6) using a generalized version of equation (5), where all the parameter estimates are assumed to vary across countries, or across $i$ 's: ${ }^{51}$

$$
Y_{i}=\sum_{j=1}^{M}\left(\alpha_{i j}+\beta^{\prime}{ }_{i j} X_{i}+\gamma^{\prime}{ }_{i j} Z_{i j}\right) n_{i j},
$$

The regression results are qualitatively similar. ${ }^{52}$ Using the parameter estimates, we can then derive country-level estimates of child mortality rate among the poor and nonpoor. We compare those estimates with estimates derived from King's method, using the same sample of 68 countries. The two sets of estimates are closely correlated. The correlation coefficient is about 0.78 for the poor and 0.61 for the nonpoor; these are statistically significant. However, there are wide differences in a number of country-level estimates. In particular, over a third of point estimates from Bidani and Ravallion fall outside the 95 percent confidence interval of King's estimates.

Appendix Figure 3 plots the estimated health status of the poor and nonpoor. The aggregate child mortality rate for each country is plotted as reference. The shaded area marks the region where we would normally not expect the estimated values to be found. For example, the mortality rate of the poor would be typically higher than average. An estimated value of less than zero would be outright impossible.

\footnotetext{
${ }^{51}$ We thank P.A.V.B. Swamy for suggesting this model.

${ }^{52}$ Public spending on health affects the poor more favorably than the nonpoor. The estimated $Y_{i j}$ 's in the two sets of regression results are close.
} 
Appendix Figure 3. Child Mortality Rate of the Poor and Nonpoor, 1990-99 (Per 1,000 live births; 95 percent confidence interval in bars)

Child mortality rate among the poor

- King's method - Bidani-Ravallion method __ Aggregate child mortality rate (act ual)

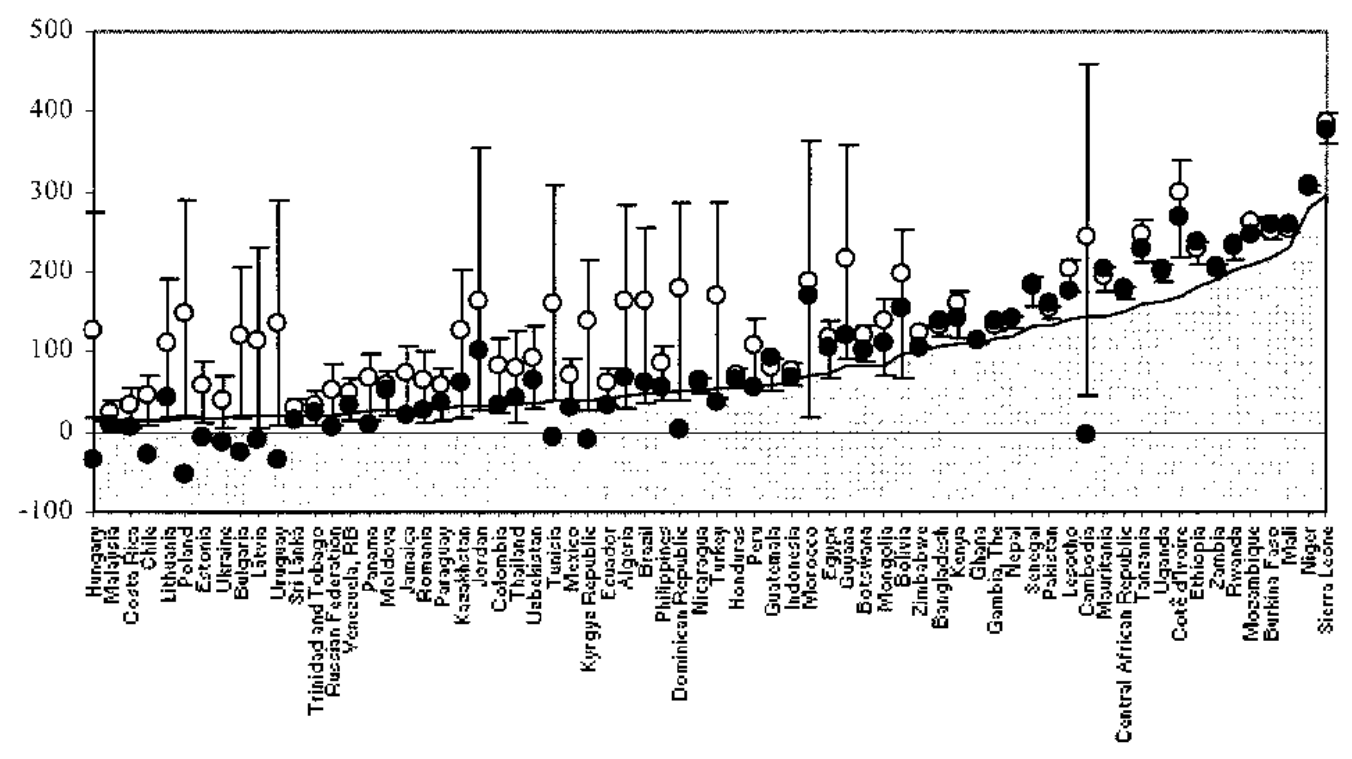

Child mortality rate among the nonpoor

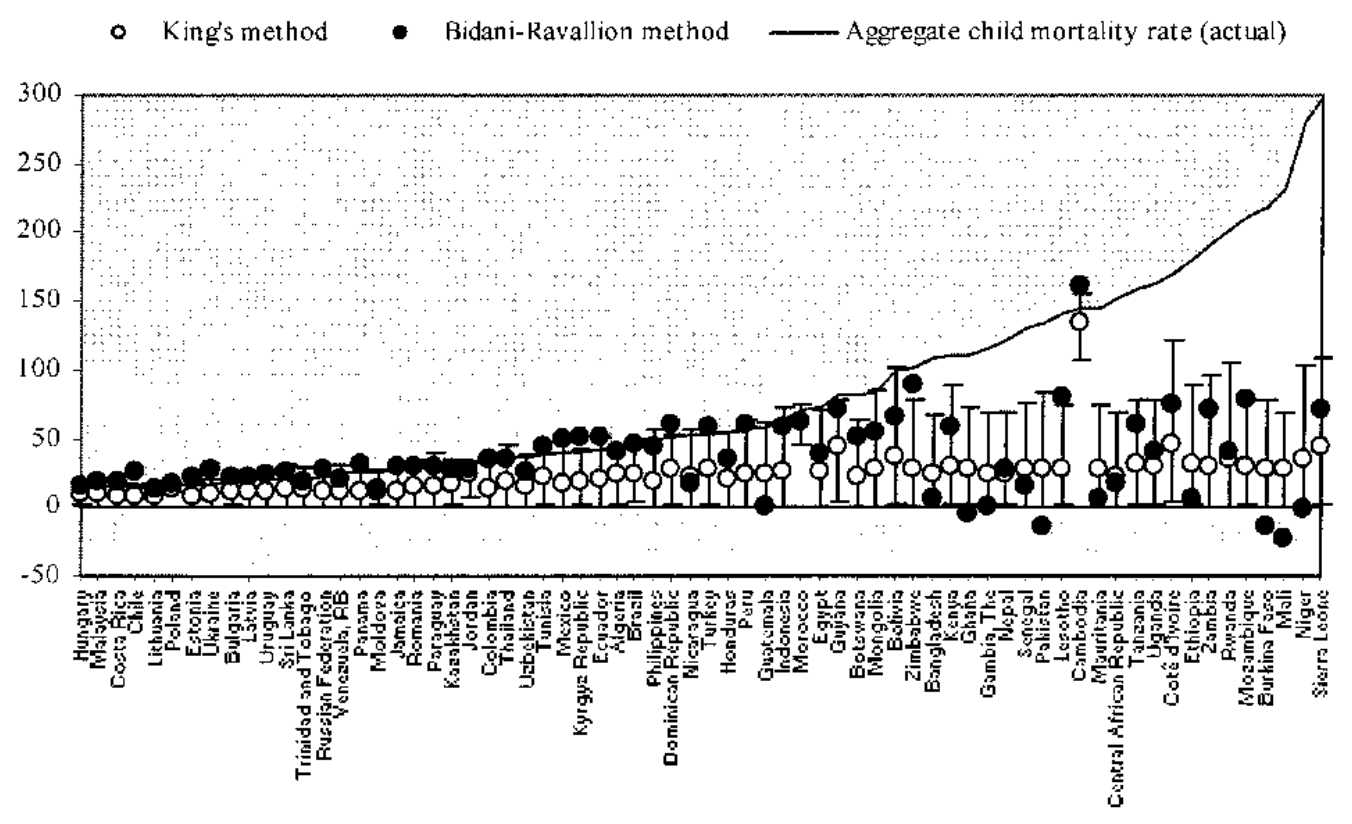

Source: World Development Indicators database; and authors' calculations. 
The figure shows that out of 68 country estimates for child mortality rates among the poor, 13 (or 19 percent) estimates from the Bidani and Ravallion method are implausible, because they are below the country-level average child mortality rate. An additional 11 estimates (16 percent) are impossible, because they are below zero. For child mortality among the nonpoor, 24 estimates ( 35 percent) are implausible and 5 estimates ( 7 percent) are impossible. In contrast, all the point estimates using King's method are within the plausible ranges.

\section{Health Status of the Poor and Nonpoor using DHS Data}

An alternative test would be to assume that the DHS quintile data described in the main text can be used to approximate the "true" values of child mortality rates among the absolute poor and nonpoor. ${ }^{53}$ For example, the child mortality rate among the poor in a country where 40 percent of the population are below the two-dollar-a-day poverty line can be approximated by the average child mortality rate of the two bottom wealth quintiles. Using aggregate data on country-level child mortality rates from DHS, King's and Bidani and Ravallion's methods can again be applied to generate estimates of the health status of the poor and nonpoor, which may then be compared with DHS data. This yields a common sample of 31 countries.

Appendix Figure 4 plots the estimated health status of the poor and nonpoor from the three data sources. Values of the aggregate child mortality rate are also plotted for reference. As in Appendix Figure 3, the shaded area marks the region where we would normally not expect the estimated values to be found, either because they are implausible or impossible.

Estimates of the health status of the poor from King's method are comparable with the DHS values (the correlation coefficient is 0.9 and is statistically significant at the 1 percent level), although a number of mortality rates are overestimated. In particular, some DHS values fall outside the 95 percent confidence interval of King's estimates. The point estimates from King's method all fall within the plausible range, however. In contrast, estimates from DHS and from the Bidani and Ravallion method fall in the shaded region. ${ }^{54}$ Some point estimates are again impossible.

53 This approximation must be made with caution: The two pieces of information required to make this approximation are drawn from two different data sources using two different measures of living standards. DHS quintile averages are calculated using assets or wealth as a proxy for income. Data on the poverty headcount are based on actual information on income or expenditure from various household surveys.

${ }^{54}$ A couple of DHS estimates fall in this shaded region. Health status does not improve monotonically with the asset index in some countries. As such, the poor seem to be doing better than the nonpoor, contrary to expectations. 
Appendix Figure 4. Child Mortality Rate of the Poor and Nonpoor, 1995 (Per 1,000 live births; 95 percent confidence interval in bars)

Child mortality rates among the poor

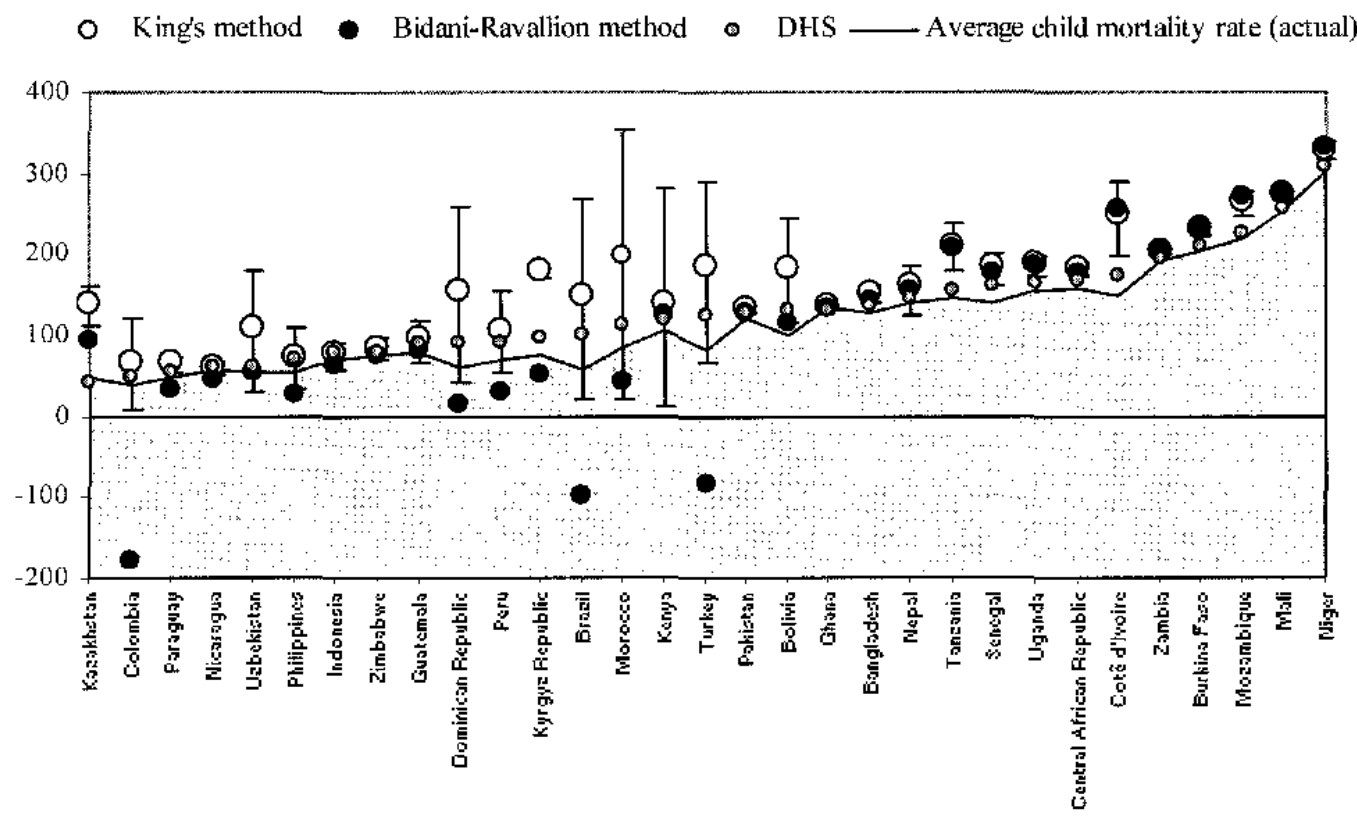

Child mortality rates among the nonpoor

- King's method - Bidani-Ravalion method - DIS —-Average child mortality rate (actual)

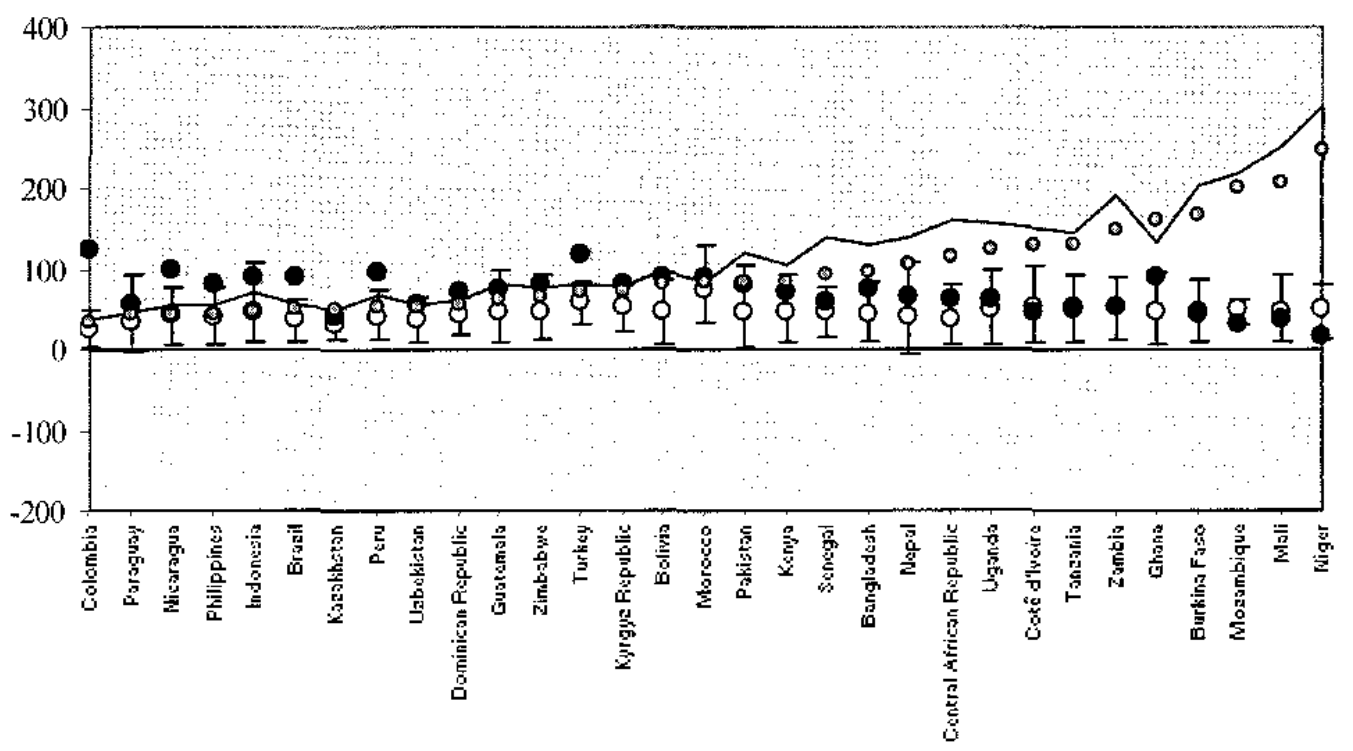

Source: Gwatkin and others, 2000; and authors' calculations. 
Estimates of the health status of the nonpoor from both King's and Bidani and Ravallion's method differ widely from the DHS estimates. If the DHS vales are assumed to represent the "true" values, King's method falls short in estimating the true health status of the nonpoor in a number of countries. Not surprisingly, these countries are relatively poor, thus providing relatively wider bounds for the distribution of the health status of the nonpoor. Between King and Bidani and Ravallion, however, point estimates from King's method fall consistently within the known plausible range. Estimates from King's method are weakly correlated with the DHS values (about 0.3 ) while estimates from Bidani and Ravallion are negatively correlated with DHS values (about -0.7 ). 


\section{References}

Ainsworth, Martha, and Mead Over, 1997, "Confronting AIDS: Public Priorities in a Global Epidemic," World Bank Policy Research Report No. 17285 (Washington: World Bank).

Anand, Sudhir, and Martin Ravallion, 1993, "Human Development in Poor Countries: On the Role of Private Incomes and Public Services," Journal of Economic Perspectives, Vol. 7 (Winter), pp. 133-50.

Baldacci, Emmanuele and Luiz de Mello, "More on the Effectiveness of Public Spending on Health Care and Education: A Covariance Structure Model," IMF Working Paper (forthcoming).

Benoit, Kenneth, and Gary King, 1996, "A Preview of EI and EzI: Programs for Ecological Inference," Social Science Computer Review, Vol. 14 (Winter), pp. 433--38.

Benzeval, Michaela, Jayne Taylor, and Ken Judge, 2000, "Evidence on the Relationship Between Low Income and Poor Health: Is the Government Doing Enough?" Fiscal Studies, Vol. 21 (September), pp. 375-99.

Bidani, Benu, and Martin Ravallion, 1997, "Decomposing Social Indicators Using Distributional Data," Journal of Econometrics, Vol. 77 (March), pp. 125-39.

Brockerhoff, M., and P. Hewett, 2000, "Inequality of Child Mortality Among Ethnic Groups in Sub-Saharan Africa," Bulletin of the World Health Organization, Vol. 78, No. 1, pp. $30-41$.

Castro-Leal, Florencia, and others, 1999, "Public Social Spending in Africa: Do the Poor Benefit?" World Bank Research Observer, Volume 14 (February), pp. 49-72.

Chang, I-Lok, Charles Hallahan, and P.A.V.B. Swamy, 1992, "Efficient Computation of Stochastic Coefficients Models," in Computational Economics and Econometrics, ed. by H. M. Amman and others (The Netherlands: Kluwer Academic Publishers).

Chang, I-Lok, P.A.V.B. Swamy, Charles Hallahan, and George S. Tavlas, 2000, “A Computational Approach to Finding Causal Economic Laws," Computational Economics, Vol. 16, Nos. 1-3 (October), pp. 105-36.

Chang, I-Lok and P.A.V.B. Swamy, 2001, "Stochastic Coefficients Estimation Program (SCEP): A User's Guide" (unpublished; Washington: American University).

Chu, Ke-young, Hamid Davoodi, and Sanjeev Gupta, 2000, "Income Distribution and Tax and Government Social Spending Policies in Developing Countries," IMF Working Paper 00/62 (Washington: International Monetary Fund). 
Davoodi, Hamid, and Dawitree Sachjapinan, "How Useful Are Benefit Incidence Studies?" IMF Working Paper (forthcoming).

Deininger, Klaus, and Lyn Squire, 1998, "New Ways of Looking at Old Issues: Inequality and Growth," Journal of Development Economics, Vol. 57 (December), pp. 259-87.

Demery, Lionel, and Michael Walton, 1998, Are Poverty Reduction and Other $21^{\text {st }}$ Century Social Goals Attainable (Washington: World Bank).

Deolalikar, Anil B., 1995, "Government Health Spending in Indonesia: Impacts on Children in Different Economic Groups," in Public Spending and the Poor: Theory and Evidence, ed. by Dominque van de Walle and Kimberly Nead (Baltimore: Johns Hopkins University Press).

Dollar, David, and Art Kraay, 2001, "Growth Is Good for the Poor," World Bank Policy Research Working Paper No. 2587 (Washington: World Bank).

Doorslaer, Eddy van, and others, 1997, "Income-Related Inequalities in Health: Some International Comparisons," Journal of Health Economics, Vol. 16 (February), pp. 93-112.

Duncan, Otis Dudley, and Beverly Davis, 1953, "An Alternative to Ecological Correlation," American Sociological Review, Vol. 18 (December), pp. 665-66.

Filmer, Deon, 2000, "The Structure of Social Disparities in Education: Gender and Wealth," World Bank Policy Research Working Paper No. 2268 (Washington: World Bank). , Jeffrey S. Hammer, and Lant H. Pritchett, 2000, "Weak Links in the Chain: A Diagnosis of Health Policy in Poor Countries," World Bank Research Observer, Vol. 15 (August), pp. 199-224.

Filmer, Deon, and Lant H. Pritchett, 1999, "The Impact of Public Spending on Health: Does Money Matter?" Social Science \& Medicine, Vol. 49 (November), pp. 1309-23. ,2001, "Estimating Wealth Effects Without Expenditure Data-Or Tears: An Application to Educational Enrollments in States of India," Demography, Vol. 38 (February), pp. 115-32.

Gakidou, E., D. Jamison, G. King and C. Spohr, 1999, "Health Status and Access to Health Services: How Different are the Poor?" (unpublished; Geneva: WHO Economics Advisory Service). 
Gakidou, Emmanuela, and Gary King, 2000, "An Individual-Level Approach to Health Inequality: Child Survival in 50 Countries," Global Programme on Evidence for Health Policy Discussion Paper No. 18 (Geneva: World Health Organization). Available via the Internet: http:/www-nt.who.int/whosis/statistics/discussion papers/pdf/paper18.pdf

Galasso, Emanuela, and Martin Ravallion, 2001, "Decentralized Targeting of an AntiPoverty Program" (unpublished; Washington: World Bank).

Gupta, Sanjeev, and others, 2001, "Debt Relief and Public Health Spending in Heavily Indebted Poor Countries," Finance \& Development, Vol. 38 (September), pp. 10-13.

Gupta, Sanjeev, Hamid Davoodi, and Rosa Alonso-Terme, 1998, "Does Corruption Affect Income Inequality and Poverty?" IMF Working Paper 98/76 (Washington: International Monetary Fund).

Gupta, Sanjeev, and Marijn Verhoeven, 2001, "The Efficiency of Government Expenditure: Experiences from Africa," Journal of Policy Modeling, Vol. 23, No. 4 (July), pp. 433-467.

Gupta, Sanjeev, Marijn Verhoeven, and Erwin Tiongson, 1999, "Does Higher Government Spending Buy Better Results in Education and Health Care?" IMF Working Paper 99/21 (Washington: International Monetary Fund).

Gwatkin, Davidson R., 1999, "Poverty and Inequalities in Health Within Developing Countries," paper presented at the Ninth Annual Public Health Forum of the London School of Hygiene and Tropical Medicine, London, April.

, 2000, "Health Inequalities and the Health of the Poor: What Do We Know? What Can We Do?" Bulletin of the World Health Organization, Vol. 78, No. 1, pp. 3-18.

Gwatkin, Davidson R., and Michel Guillot, 2000, The Burden of Disease Among the Global Poor: Current Situation, Future Trends, and Implications for Strategy, Health, Nutrition, and Population Series (Washington: World Bank).

Gwatkin, Davidson R., and others, 2000, Socio-Economic Differences in Health, Nutrition, and Population, Health, Nutrition, and Population Series, various issues (Washington: World Bank).

International Monetary Fund, and others, 2000, 2000: A Better World for All: Progress Toward the International Development Goals (Washington: Communications Development).

Jack, William, 1999, Principles of Health Economics for Developing Countries (Washington: World Bank). 
Kakwani, N., 1993, "Performance in Living Standards: An International Comparison," Journal of Development Economics, Vol. 41 (August), pp. 307-336.

King, Gary, 1997, A Solution to the Ecological Inference Problem: Reconstructing Individual Behavior from Aggregate Data (Princeton, New Jersey: Princeton University Press).

King, Gary, Ori Rosen, and Martin A. Tanner, 1999, "Binomial-Beta Hierarchical Models for Ecological Inference," Sociological Methods \& Research, Vol. 28 (August), pp. 61-90.

Le Grand, Julian, 1987, "Inequalities in Health: Some International Comparisons," European Economic Review, Vol. 31 (February/March), pp. 182-91.

Makinen, M., and others, 2000, "Inequalities in Health Care Use and Expenditures: Empirical Data from Eight Developing Countries and Countries in Transition," Bulletin of the World Health Organization, Vol. 78, No. 1, pp. 55-65.

Montgomery, Mark R., and others, 1999, "Measuring Living Standards with Proxy Variables," Policy Research Division Working Paper No. 129 (New York: The Population Council).

Prescott, Nicholas, and Dean T. Jamison, 1985, "The Distribution and Impact of Health Resource Availability in China, International Journal of Health Planning and Management, Vol. 1 (June), pp. 45-56.

Pritchett, Lant, and Lawrence H. Summers, 1996, "Wealthier is Healthier," Journal of Human Resources, Vol. 31, No. 4, pp. 841-68.

Ravallion, Martin, 1996, "How Well Can Method Substitute for Data? Five Experiments in Poverty Analysis," World Bank Research Observer, Vol. 11 (August), pp. 199-221. , 1999a, "Are Poorer States Worse at Targeting Their Poor?" Economics Letters, Vol. 65 (December), pp. 373-377.

, 1999b, "Is More Targeting Consistent with Less Spending?" International Tax and Public Finance, Vol. 6, No. 3, pp. 411-19.

,2000, "Monitoring Targeting Performance When Decentralized Allocations to the Poor Are Unobserved," World Bank Economic Review, Vol. 14, No. 2, pp. 331-45.

Ravallion, Martin, and Shaohua Chen, 1997, "What Can New Survey Data Tell Us About Recent Changes in Distribution and Poverty?" World Bank Economic Review, Vol. 11, No. 2, pp. 357-82. 
Schultz, T. Paul, 1993, "Mortality Decline in the Low-Income World: Causes and Consequence," Economic Growth Center Discussion Paper No. 681 (New Haven: Yale University).

___ 1998, "The Formation of Human Capital and the Economic Development of Africa: Returns to Health and Schooling Investments," Economic Research Paper No. 37 (Côte d'Ivoire: African Development Bank).

Stanton, Bonita, 1994, "Child Health: Equity in the Non-Industrialized Countries," Social Science and Medicine, Vol. 38, No. 10, pp. 1375-83.

Swamy, P.A.V.B., and George S. Tavlas, 2001, "Random Coefficient Models: Theory and Applications," in A Companion to Theoretical Econometrics, ed. by Badi H. Baltagi (Malden: Blackwell Publishers Ltd.), pp. 410-28.

Swamy, P.A.V.B., and P.A. Tinsley, 1980, "Linear Prediction and Estimation Methods for Regression Models with Stationary Stochastic Coefficients," Journal of Econometrics, Vol. 12 (February), pp. 103-42.

Wagstaff, Adam, 2000, "Socioeconomic Inequalities in Child Mortality: Comparisons Across Nine Developing Countries," Bulletin of the World Health Organization, Vol. 78, No. 1, pp. 19-29.

Wagstaff, Adam, and Naoko Watanabe, 2000, "Socioeconomic Inequalities in Child Malnutrition in the Developing World," World Bank Policy Research Working Paper No. 2434 (Washington: World Bank).

Wang, Limin, 2001, "Health Outcomes in Poor Countries and Policy Options: A Summary of Empirical Findings from the DHS Data" (unpublished; Washington: World Bank).

World Bank, 1995, "Philippines: Public Expenditure Management for Sustained and Equitable Growth," World Bank Report No. 14680-PH (Washington: World Bank). ,2001, World Development Indicators 2001 (Washington: World Bank).

World Health Organization, 1999, World Health Report 1999: Making a Difference (Geneva: World Health Organization). ,2000, World Health Report 2000: Health Systems: Improving Performance (Geneva: World Health Organization). 